\title{
Optimising nutrient removal of a hybrid five-stage Bardenpho and moving bed biofilm reactor process using response surface methodology
}

Ashrafi, Elham; Mehrabani Zeinabad, Arjomand; Borghei, Seyed Mehdi; Torresi, Elena; Muñoz Sierra, Julian

Published in:

Journal of Environmental Chemical Engineering

Link to article, DOI:

10.1016/j.jece.2018.102861

Publication date:

2019

Document Version

Peer reviewed version

Link back to DTU Orbit

Citation (APA):

Ashrafi, E., Mehrabani Zeinabad, A., Borghei, S. M., Torresi, E., \& Muñoz Sierra, J. (2019). Optimising nutrient removal of a hybrid five-stage Bardenpho and moving bed biofilm reactor process using response surface methodology. Journal of Environmental Chemical Engineering, 7(1), [102861].

https://doi.org/10.1016/j.jece.2018.102861

\section{General rights}

Copyright and moral rights for the publications made accessible in the public portal are retained by the authors and/or other copyright owners and it is a condition of accessing publications that users recognise and abide by the legal requirements associated with these rights.

- Users may download and print one copy of any publication from the public portal for the purpose of private study or research.

- You may not further distribute the material or use it for any profit-making activity or commercial gain

- You may freely distribute the URL identifying the publication in the public portal 


\section{Accepted Manuscript}

Title: Optimising nutrient removal of a hybrid five-stage Bardenpho and moving bed biofilm reactor process using response surface methodology

Authors: Elham Ashrafi, Arjomand Mehrabani Zeinabad, Seyed Mehdi Borghei, Elena Torresi, Julian Muñoz Sierra

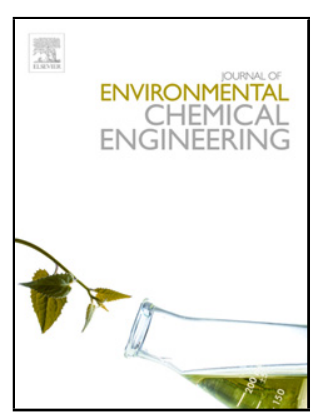

PII:

DOI:

S2213-3437(18)30784-X

Article Number: 102861

Reference: $\quad$ JECE 102861

To appear in:

Received date: $\quad 8$ August 2018

Revised date: $\quad 22$ December 2018

Accepted date: 23 December 2018

Please cite this article as: Ashrafi E, Zeinabad AM, Borghei SM, Torresi E, Muñoz Sierra J, Optimising nutrient removal of a hybrid five-stage Bardenpho and moving bed biofilm reactor process using response surface methodology, Journal of Environmental Chemical Engineering (2018), https://doi.org/10.1016/j.jece.2018.102861

This is a PDF file of an unedited manuscript that has been accepted for publication. As a service to our customers we are providing this early version of the manuscript. The manuscript will undergo copyediting, typesetting, and review of the resulting proof before it is published in its final form. Please note that during the production process errors may be discovered which could affect the content, and all legal disclaimers that apply to the journal pertain. 


\section{Optimising nutrient removal of a hybrid five-stage Bardenpho and moving bed biofilm reactor process using response surface methodology}

Elham Ashrafi ${ }^{\mathrm{a}}$, Arjomand Mehrabani Zeinabad ${ }^{\mathrm{a}}$, Seyed Mehdi Borghei $^{\mathrm{b}^{*}}$, Elena Torresi ${ }^{\mathrm{c}, \mathrm{d}}$, Julian Muñoz Sierra ${ }^{e, f}$

${ }^{a}$ Chemical Engineering Department, Isfahan University of Technology, Isfahan, Iran

${ }^{\mathrm{b}}$ Biochemical and Bioenvironmental Engineering Research Center (BBRC), Sharif University of Technology, Tehran, Iran

${ }^{c}$ DTU Environment, Technical University of Denmark, Bygningstorvet B115, 2800 Kongens Lyngby, Denmark

${ }^{\mathrm{d}}$ Veolia Water Technologies AB, AnoxKaldnes, Klosterängsvägen 11A, SE-226 47 Lund, Sweden

${ }^{\mathrm{e}}$ Section Sanitary Engineering, Department of Water Management, Delft University of Technology, Stevinweg 1, 2628CN, Delft, The Netherlands

${ }^{\mathrm{f}}$ KWR Watercycle Research Institute, Groningenhaven 7, 3430 BB, Nieuwegein, The Netherlands

*Corresponding author: Seyed Mehdi Borghei (mborghei@ sharif.edu), Tel: +98-912-113-0394 


\section{Graphical abstract}

Hybrid Five Stages Bardenpho-MBBR process

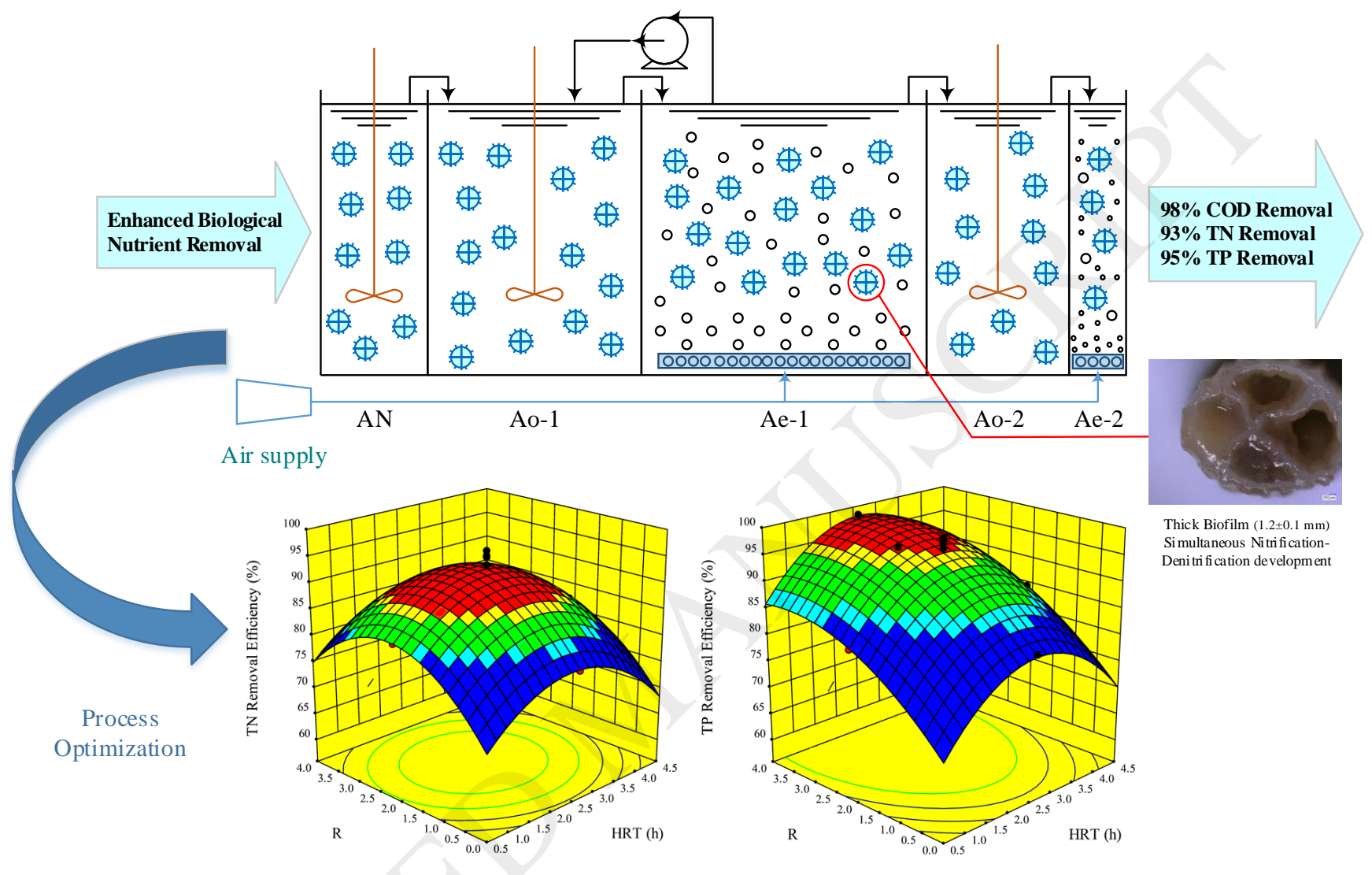




\title{
Highlights
}

- Enhanced nutrient removal was achieved in a hybrid 5-stage Bardenpho-MBBR system

- Maximum nitrogen and phosphorous removal efficiencies were about $93 \%$ and $95 \%$

- An anaerobic HRT of $2 \mathrm{~h}$ and nitrate recycle ratio $\mathrm{R}$ of 2 were the suitable operational values

- Attached biofilm nitrifying activity was about 4 times higher than in suspended biomass

- Suspended biomass showed higher COD removal according to oxygen uptake rates

\begin{abstract}
Nutrient pollution has become a global environmental issue. Innovative biological nutrient removal (BNR) processes are needed to overcome the drawbacks of conventional technologies. This study evaluates the potential of a hybrid 5-stage Bardenpho - moving bed biofilm reactor (MBBR) process for organic carbon and nutrient removal from municipal wastewater at different hydraulic retention time (HRT) and nitrate recycle ratio (R). Response surface methodology (RSM) based on a central composite design (CCD) of thirteen experiments was applied to optimize the nitrogen and phosphorus conversion of the treatment system. High removal efficiencies of about $98.20 \%, 92.54 \%, 94.70 \%$ and $96.50 \%$ for total chemical oxygen demand (COD), total nitrogen (TN), total phosphorus (TP) and ammonium, were achieved, respectively. The best performance was observed at HRT of 2, 4, 6, 2.67 and 1.07 hours correspondingly in the anaerobic, first anoxic, first aerobic, second anoxic and second aerobic compartments, resulting in a total HRT of 15.74 hours with a nitrate recycle ratio of 2. Biofilm nitrifying activity was four times higher than in suspended biomass. The hybrid 5-stage Bardenpho-MBBR process enhanced biological nutrient removal at comparatively short HRT and low $\mathrm{R}$ ratio due to biofilm contribution to the conversion.
\end{abstract}


Keywords: Bardenpho process, nutrient removal, biofilm reactor, process optimization, response surface methodology 


\section{Introduction}

Wastewater streams with high nutrient content (nitrogen and phosphorus) can be the leading reason for several issues when discharged into the environment, such as oxygen consumption, eutrophication and toxicity (Leyva-Díaz et al., 2016). Consequently, the nutrient pollution has turned out to be a global environmental threat (Peng and Ge, 2011; Wang et al., 2014; Reza and Cuenca, 2016). In last decades, biological nutrient removal (BNR) processes have been comprehensively studied. BNR processes typically rely on an arrangement of different environmental redox conditions (anaerobic, anoxic and aerobic) into separate compartments (Asadi et al., 2016). Concisely, nitrogen $(\mathrm{N})$ and phosphorus $(\mathrm{P})$ are undertaken by heterotrophic organisms capable of denitrification and polyphosphate accumulation. A major drawback with conventional BNR systems is highlighted by massive reactor volumes requirement, which make them often unfeasible in terms of investment and space. Furthermore, the overall efficiency of the process is strictly depending on the solid-liquid separation accomplished in the clarifier, which may be deteriorated by poor biomass settling characteristics (Wanner, 2003). As a result over the last years, a number of studies have been carried out targeting innovative solutions with the aim of overcoming the main drawbacks of the conventional BNR configurations (Fu et al., 2009; Di Trapani et al., 2014). Among the novel technologies, membrane bioreactors (MBR), moving bed biofilm reactors (MBBR) and MBBR-based Integrated Fixed Film Activated Sludge (IFAS) reactors have captured attention due to their advantages compared to conventional processes (Di Trapani et al., 2014). Especially, MBBR systems using polymeric carrier elements for biofilm growth, are considered as a promising solution (Ødegaard, 2006). The advantage of MBBR-based processes is the presence of both suspended flocs and biofilm in the same reactor compartment (Mannina et al., 2011; Di Trapani et al., 2013). Hence, application of attached growth in MBBR allows to have a compact reactor with higher biomass concentration compared to conventional 
BNR (Barwal and Chaudhary, 2014). MBBR has been applied for synthetic (Bassin et al., 2012; Hoang et al., 2014), domestic (Bassin et al., 2011) and industrial wastewater treatment (Li et al., 2003; Dvoř́k et al., 2014; Bering et al., 2018). Slow biofilm formation rate during start-up could be one of the drawbacks on the practical applications of MBBR (Gu et al., 2018). Combination of MBBR and BNR systems have been reported, for example, Lai et al. (2011) applied a modified Anaerobic/Anoxic/Oxic $\left(\mathrm{A}^{2} \mathrm{O}\right)$ process based on a plastic-based biofilm support media to remove organics and nutrients from municipal wastewater. Compared to a traditional $\mathrm{A}^{2} \mathrm{O}$ process the chemical oxygen demand (COD), total nitrogen (TN), and total phosphorus (TP) removal efficiencies increased from $91 \%, 48 \%$ and $56 \%$ to $98 \%, 73 \%$ and $71 \%$, respectively. Mannina et al. (2016); (2017) evaluated a hybrid MBBR-MBR-UCT (University of Cape Town) process and achieved removal efficiencies of about $98 \%, 60 \%$ and $77 \%$ for COD, TN and TP, respectively at a $\mathrm{C} / \mathrm{N}$ ratio of 10. Leyva-Díaz et al. (2016) evaluated a hybrid MBBR-MBR containing carriers in the anaerobic, anoxic and aerobic compartments and another with carriers only in the anaerobic and anoxic compartments. It was reported higher COD and TP removal efficiencies in the first system and the highest TN removal efficiency $(61.39 \pm 10.71 \%)$ in the latter. Recently, Ooi et al. (2018) evaluated six moving bed biofilm reactors (MBBRs) in series targeting carbon, nutrients, and pharmaceutical/micropollutants removal. Interestingly, out of the 22 pharmaceutical/micropollutants studied, 17 compounds were removed higher than $20 \%$. Some studies were carried out focusing on the hydraulic retention time (HRT) influence in BNR systems. Bassin et al. (2016) operated the MBBR system filled with different support media for simultaneous nitrification-denitrification (SND) under different organic loading rates and HRTs. They reported TN removal efficiencies up to $86 \%$ and $73 \%$ in MBBR filled with Kaldnes $\mathrm{K}_{1}$ and Biochip carriers, respectively at HRT of 12 hours. Zhang et al. (2016) revealed that the HRT has a significant effect on the reliability and stability of BNR systems, meanwhile, HRT is a 
fundamental parameter for wastewater treatment plants (WWTPs) design and operation, which directly affect the infrastructure and operational cost. They found that HRT played a key role in enhancing denitrifying phosphorus removal and preventing secondary phosphorous release. Moreover, Akratos and Tsihrintzis (2007), and Xu et al. (2014) have investigated various HRTs for optimal nutrient removal in BNR systems. Another critical parameter for BNR performance is the nitrate recycle ratio (R). Larger R conveys a surplus of dissolved oxygen (DO) from the aerobic to anoxic compartments and as a result deteriorates the denitrification process, on the other hand, low R decreases the returned nitrate and reduces the TN removal (Chen et al., 2011; Chen et al., 2015). Chen et al. (2011); (2015) reported an operation of the Bardenpho system at different recycle ratios. However, the hybrid 5-stage Bardenpho-MBBR process is rather new and a few research studies reported the impact of operational parameters on system performance as well as the activity of suspended and attached biomass. Additionally, it is still unclear what would be an effective HRT in each compartment of a biofilm 5-stage Bardenpho system. Moreover, it has not been yet determined which $\mathrm{R}$ values are the most appropriate for enhancing the nutrient removal. Also, the assessment of biofilm capability for simultaneously nitrificationdenitrification (SND) to improved nitrogen removal has not been reported. Therefore, this study aimed to evaluate and optimize the performance potential of a hybrid 5-stage Bardenpho-MBBR process on organic and nutrient removal efficiencies through response surface methodology based on the parameters HRT and the nitrate recycle ratio. Furthermore, biofilm contribution on nitrification activity was assessed. This study provides valuable knowledge for the application of the MBBR system in BNR process for municipal wastewater treatment to fulfil stringent discharge requirements. 


\section{Experimental}

\subsection{Experimental set-up}

A lab-scale system was built-up according to the 5-stage Bardenpho scheme. The set-up consisted of an influent tank and five compartments (one anaerobic, two anoxic and two aerobic) in series. All compartments were made of transparent Plexiglas in a rectangular shape (Fig 1). The effective volume of the first aerobic compartment (Ae-1) was regulated to maintain a constant HRT throughout the experiment. Mechanical stirrers with a rectangular paddle were installed in the anaerobic and anoxic zones to keep the sludge and carriers in suspension. Besides, air bubble diffusers were installed at the bottom of the aerobic zones to facilitate mixing. Total aeration rate was $0.18-0.20 \mathrm{~m}^{3} / \mathrm{h}$. Every compartment was packed with Kaldnes $\mathrm{K}_{1}$ carriers with a $30 \%, 40 \%$ and $50 \%$ filling ratio in the anaerobic, anoxic, and aerobic compartments, respectively. The carriers' characteristics are presented in Table 1. The influent was pumped into the anaerobic compartment and the nitrate, product of the nitrification process in the aerobic compartment, was recycled into the anoxic compartment to be used as an electron acceptor for phosphorus removal and denitrification. The influent and nitrate recycle flow rates were controlled by a peristaltic pump (Longer pump, WT600-1F, USA).

\subsection{Influent synthetic wastewater}

The system was inoculated with activated sludge taken from the Ekbatan Sewage Treatment Plant (Tehran, Iran). The initial total suspended solids (TSS) and volatile suspended solids (VSS) were $2.5 \mathrm{~g} / \mathrm{L}$ and $1.2 \mathrm{~g} / \mathrm{L}$ respectively. The synthetic wastewater was composed of a medium A consisting of: $0.8 \mathrm{gCOD} / \mathrm{L}$ (a mixture of glucose and sodium acetate with molar ratio of 1:1); 3.6mM MgSO $4.7 \mathrm{H}_{2} \mathrm{O} ; 4.7 \mathrm{mM} \mathrm{KCl}$, and medium B consisting of: $69 \mathrm{mM} \mathrm{NH} 4 \mathrm{Cl} ; 4.2 \mathrm{mM}$ $\mathrm{K}_{2} \mathrm{HPO}_{4} ; 2.1 \mathrm{mM} \mathrm{KH} 2 \mathrm{PO}_{4} ; 15 \mathrm{~mL}$ milk; and $10 \mathrm{~mL} / \mathrm{L}$ trace element solution, all according to 
Vishniac and Santer (1957). On every time $150 \mathrm{~mL}$ of both media was dosed to the reactor together with 1.2 L of tap water De Kreuk et al. (2010).

\subsection{System operational conditions}

Temperature and $\mathrm{pH}$ were kept at $25-28^{\circ} \mathrm{C}$ and $7.0-7.5$ in all the reactors by using a water bath and $\mathrm{pH}$ probes (WTW, Germany). DO concentration was controlled at $3 \mathrm{mg} / \mathrm{L}$ in both aerobic compartments. Influent COD, TN, and TP, were in the range of 700-800, 35-40 and 7-8 mg/L, respectively. The flow rate was $216 \mathrm{~L} / \mathrm{d}$. The working volume of each compartment varied depending on the corresponding HRT for each run. However, the compartment Ae-1 had a fixed volume and HRT (6 hours) throughout the experiments. Table 2 indicates HRT in all compartments with their corresponding operational conditions. The system was operated for 40 days as start-up period and 273 days along with thirteen experimental runs. Each run was carried for 21 days.

\subsection{Statistical design of experiments, data analysis, and optimization}

A two-factor central composite design (CCD) was performed using the statistical Design-Expert software, version 10.0.2.0 (Stat- Ease Inc., Minneapolis, MN, USA) to analyze the significance of experimental results (Gallego et al., 2009). Both experimental conditions and their responses (TN and TP removal efficiencies) are presented in Table 2, as well as the organic (OLR) and nitrogen loading rates (NLR). The range and the levels of the independent variables are presented in Table 3. The two independent factors $\left(\mathrm{HRT}_{\mathrm{AN}}\right.$ and $\left.\mathrm{R}\right)$ were studied at five different levels. The HRT of the other compartments were calculated based on their volume correlation. Thereby, a central composite design for two independent variables at each of the five levels was used to fit the model with a total of 13 experimental runs required for this procedure. A multiple regression 
model was obtained to estimate the predicted value of the dependent variables (Oberoi and Sogi, 2017). A second order polynomial regression model was used to express the response $Y$ as a function of the independent factors as follows:

$$
Y=b_{0}+\sum_{n=1}^{2} b_{n} X_{n}+\sum_{n=1}^{2} b_{m n} X_{n}^{2}+\sum_{n<m}^{2} b_{n m} X_{n} X_{m}
$$

where $\mathrm{Y}$ is the dependent variable i.e. TN removal efficiency; $\mathrm{X}$ is the independent variables such as HRT, $R ; b_{0}$ is the constant value at central point; $b_{n}, b_{m}$ and $b_{n m}$ are the linear, quadratic and cross product coefficients.

\subsection{Biomass oxygen uptake and nitrification rates}

In order to assess the specific nitrifying activity of the both attached and suspended biomass and estimate the amount of ammonium oxidized by each biomass fraction in Ae-1 zone, batch tests were carried out according to the methods described by Bassin et al. (2016). Briefly, the reactor feeding was stopped, and a pulse of a concentrated stock solution of ammonium chloride was added to reach an initial ammonium concentration similar to that of the reactor influent. Samples were collected every $20 \mathrm{~min}$ for $6 \mathrm{~h}$. The volumetric ammonium removal rate was calculated by linear regression of ammonium concentration over time. The biomass-specific ammonium removal rate was determined by dividing the volumetric ammonium removal rate by the total amount of biomass (i.e., volatile total solids (VTS) $=$ volatile attached solids (VAS) + volatile suspended solids (VSS)). Subsequently, all the carriers were removed to evaluate the nitrification rate of the suspended solids. Respirometric batch experiments were carried out along with the procedure described by Mannina et al. (2016). Biomass samples were aerated until endogenous conditions were achieved, by measuring the specific oxygen uptake rate (SOUR) values.

\subsection{Analytical methods}


Total suspended solids (TSS), volatile suspended solids (VSS) and biofilm density were calculated for suspended and attached biomass as described by De Kreuk et al. (2005) and Bassin et al. (2016), respectively. Biofilm thickness was determined by microscopy. Twice a week influent wastewater and mixed liquor of the distinctive compartments were collected and filtered through a $0.45 \mu \mathrm{m}$ filter paper. The analysis of $\mathrm{COD}$, ammonium $\left(\mathrm{NH}_{4}{ }^{+}-\mathrm{N}\right)$, nitrite $\left(\mathrm{NO}_{2}{ }^{-}-\mathrm{N}\right)$, nitrate $\left(\mathrm{NO}_{3}{ }^{-}-\mathrm{N}\right)$ and orthophosphate $\left(\mathrm{PO}_{4}{ }^{3-}-\mathrm{P}\right)$ were carried out according to standard methods (APHA, 2005). TN was determined by means of $\mathrm{NH}_{4}{ }^{+}-\mathrm{N}, \mathrm{NO}_{2}^{-}-\mathrm{N}$ and $\mathrm{NO}_{3}{ }^{-}-\mathrm{N}$ concentrations addition.

\section{Results and discussion}

\subsection{Process performance}

$\mathrm{COD}, \mathrm{NH}_{4}{ }^{+}-\mathrm{N}, \mathrm{NO}_{3}{ }^{-}-\mathrm{N}, \mathrm{TN}$, and TP concentrations in the effluent and corresponding achieved removal efficiencies are depicted in Fig 2. The $\mathrm{NO}_{2}^{-}-\mathrm{N}$ and $\mathrm{N}_{\text {org }}-\mathrm{N}$ in the effluent were neglected due to their minimum concentration compared to other compounds $(<0.2 \mathrm{mg} / \mathrm{L})$. The COD results (Fig 2. A) indicated that despite the gradual increase of the total HRT during runs 1 to 4 , the COD removal within this period was roughly stable and higher than $95 \%$. Notably, the high COD removal efficiency at run $2(98 \%)$ was related to the improvement in nitrate removal efficiency (Fig 2.D), since the more denitrification took place, the more COD was consumed. Such as high COD removal could be attributed to the biofilm contribution when compared with values obtained by Huang et al. (2017) from the conventional activated sludge 5-stage Bardenpho system. The achieved $\mathrm{NH}_{4}{ }^{+}-\mathrm{N}$ removal in the whole process was about $95 \%$ (Fig 2.B). The growth of biofilm on the carriers in the aerobic compartment enhanced the nitrification process likely due to the high retention time of biofilm on the carriers, which is in agreement with previous studies (Di Trapani et al., 2014; Mannina et al., 2017). According to the achieved COD 
and $\mathrm{NH}_{4}^{+}-\mathrm{N}$ removal efficiencies (see Fig 2.A, B) of about $95 \%$ in the whole process, it can be inferred that HRT variation did not have a significant effect on them when compared with TN, nitrate and TP removal efficiencies (Fig 2.C, 2.D and 2.E).

A larger nitrate recycle ratio induced a higher $\mathrm{NO}_{3}{ }^{-} \mathrm{N}$ concentration and DO recirculation in Ao1, and therefore a higher COD removal. DO recirculation not only induced the aerobic oxidation of COD but also it promoted the aerobic oxidation of ammonium in the Ao- 1 compartment (Chen et al., 2015). Thereby, an increase in removal efficiencies was observed during runs 6 to 9, while from run 8 to 9 a minimum increase at COD degradation pointed out that the system was being operated under the maximum denitrification rate, suggesting that a $R \geq 4$ will not be recommended from the technical-economical point of view.

TN removal improved from run 1 to run 2 (up to $96.1 \%$ ) due to the higher $\mathrm{HRT}_{\text {Ao-1 }}$ which increased the time feasible for denitrification. However, removal decreased to $83 \%$ in runs 3 and 4 (Fig 2.C). Longer HRT $_{\text {Ao-1 }}$ (more than $5 \mathrm{~h}$ ) resulted in low carbon concentration for denitrifiers in Ao-1 compartment since most of the organic carbon was consumed by the Phosphate Accumulating Organisms (PAOs), which compete with denitrifiers on nutrient sources (Brown et al., 2011). Consequently, denitrification and TN efficiency declined during runs 3 and 4. TN removal efficiency declined to $80 \%$ in run 5 due to nitrate recycle elimination. The reason behind is likely related to the decline of denitrification in run 5 (Fig 2.D) because of $\mathrm{NO}_{3}{ }^{-}-\mathrm{N}$ shortage. When $\mathrm{R}$ increased from 0 to 2 , the higher amount of nitrate delivered to the Ao-1 compartment resulted in an enhanced TN removal efficiency trend during run 6 to 8 , up to $93 \%$ (Fig 2.C). At run 9, a higher R brought an excess DO from Ae-1 to the Ao-1 compartment. As a result, the accessible organic carbon for denitrification was degraded, and TN removal efficiency was deteriorated to $84 \%$ (Fig 2.C). A remarkable TN removal was achieved compared to 
previous studies in which a biofilm reactor was not used with $72 \%, 75 \%$ and $58 \%$ of $\mathrm{TN}$ removal efficiency, respectively (Lim et al., 2009; Zubrowska-Sudol and Walczak, 2015; Wang and Chen, 2016). This is likely due to the simultaneous nitrification and denitrification (SND) process occurred in the biofilm, despite the aerobic conditions in the aerobic compartment (DO ranging from 2 to $3 \mathrm{mg} / \mathrm{L}$ ). The thick biofilm (average thickness of $1.2 \pm 0.1 \mathrm{~mm}$ ) attached to the carrier may have resulted in oxygen mass transport limitation and thus, anoxic conditions in the inner zones of the biofilm (Bassin et al., 2016).

TP removal efficiency improved from $83.2 \%$ in run 1 to $98.1 \%$ in run 3 . However, it deteriorated to $84.2 \%$ in run 4 (Fig 2.E). The increase of $\mathrm{HRT}_{\mathrm{AN}}$ promoted the anaerobic phosphorus release and eventually increased the overall phosphorus removal. The substantial phosphorus uptake observed in run 3 might be attributed to denitrifying phosphorus removal (P-uptake by Denitrifying Phosphate Accumulating Organisms (DPAOs), (Hu et al., 2002; Wang et al., 2009; Ge et al., 2011; Bassin et al., 2012). On the other hand, lower TP removal at run 4 (82\%) may indicate secondary phosphorous release. This phenomenon occurs when PAOs release phosphorus without storing polymerized volatile fatty acids (VFAs). Consequently, a lack of energy to uptake all of the released phosphorus would occur in the anaerobic compartment and the released phosphorous may be not up-taken by the PAOs in the anoxic or aerobic compartments (Brown et al., 2011). Secondary phosphorus release also may occur at long HRT of the main anoxic compartment $\left(\mathrm{HRT}_{\mathrm{Ao}-1}\right)$, when nitrates are consumed before the end of the HRT, due to the fact that DNPAOs, which utilize nitrate as an electron acceptor to uptake the released phosphate, do not have adequate nitrate concentration for denitrifying phosphorus removal (Mulkerrins et al., 2004). Also, Wang and Park (2001) showed that long HRT $_{\text {AN }}$ (>3 hours) decreased the polyhydroxybutyrate (PHB) in the biomass which is crucial for phosphate uptake. A high $\mathrm{R}$ from run 6 to $9(\mathrm{R}=2)$, conveyed more nitrate to the Ao-1 compartment, which 
led to denitrifying P removal. The DNPAOs would not compete with the ordinary heterotrophic organisms for nitrate and could use the excess nitrate for denitrifying phosphorus removal, provided that the nitrate load was adequately high to exceed the denitrification potential of ordinary heterotrophic organisms (Chen et al., 2015). This also explains the declined TP removal efficiency at run 5 (P-uptake only occurred in the Ae-1 compartment).

During run 10 and 11, TN removal slightly decreased from $91 \%$ to $89 \%$, while TP removal exhibited a significant improvement due to increase of $\mathrm{R}$ value. During run 11 and 13, TP gradually decreased from $96 \%$ to $90 \%$ possibly due to secondary phosphorus release (from run 11 to 12 ) and nitrate shortage because of the decreased $\mathrm{R}$ from 2.5 to 1.5 in run 13 . The results regarding the TP removal in this study were higher than the range reported by recent literature, for instance, Huang et al. (2017), who employed the 5-stage Bardenpho system without biofilm, achieved 90\% in TP removal efficiency. The abundance of the PAOs in the anaerobic tank (possibly present on the biofilm) might have contributed to the higher phosphorus removal efficiency in this study. In addition, Yang et al. (2014) obtained the TP removal of $85.05 \pm 8.02 \%$ in a membrane-coupled MBBR, Luo et al. (2014) estimated around $89 \%$ of $\mathrm{PO}_{4}^{-3}-\mathrm{P}$ removal in an MBBR system under 24h of total HRT and 20\% of filling fraction in the bioreactor. Moreover, Kermani et al. (2008), (2009) evaluated the TP removal efficiency in a lab-scale MBBR system, which showed a performance of $87.92 \%$ and $89.73 \%$ on average, respectively.

TN removal efficiency indicated a decline during run 11 to 12 (from $89 \%$ to $87 \%$ ) and an improvement at run 13 (89\%). Lack of carbon source for denitrifiers in Ao-1 compartment limited the nitrogen reduction during run 11 to 12 and the decrease of $\mathrm{R}$ from 2.5 to 1.5 , induced the improvement in run 13.

\subsection{COD and nutrients removal at each compartment}


The best process performance was obtained at a combined $\mathrm{HRT}_{\mathrm{AN}}$ of $2.5 \mathrm{~h}$ and an $\mathrm{R}$ of 2 , at run 2 (day 62 to 82). The major proportion (76\%) of COD within the hybrid 5-stage Bardenpho-MBBR system was removed in the anaerobic compartment (AN) (Fig 3). Simultaneously, 13\% and 6\% COD was consumed in the Ao- 1 and Ae-1 compartments, respectively. The hybrid BardenphoMBBR system displayed a proper performance on organic carbon removal with a total COD removal efficiency of about $98 \%$. $\mathrm{NH}_{4}{ }^{+}-\mathrm{N}$, which was the main fraction of $\mathrm{TN}$, decreased to 25 , 8, 3.5, 1.3 and $1 \mathrm{mg} / \mathrm{L}$ in AN, Ao-1, Ae-1, Ao-2 and Ae-2 compartments, respectively. The sharp decrease in ammonium concentration at Ao-1 was due to the oxygen utilization, which was taken from Ae-1 to Ao-1 through internal recycle. The change of TN was similar to ammonium, and its removal efficiency was $92.5 \%$. TP increased to $14 \mathrm{mg} / \mathrm{L}$ in $\mathrm{AN}$ compartment due to phosphorus release. After it was gradually reduced in further compartments as Ao-1 (8 mg/L), Ae-1 (2 mg/L), Ao-2 (1.2 mg/L) and eventually Ae-2 $(0.5 \mathrm{mg} / \mathrm{L})$. Based on the results in each compartment and in the overall system, the hybrid 5-stage Bardenpho-MBBR system can be taken into consideration as a potential technology for wastewater treatment as exhibited a superior COD, ammonium, TN and TP removal efficiencies.

\subsection{Statistical data analysis and optimization}

\subsubsection{Fitting model for $T N$ and TP removal}

The analysis of variance (ANOVA) of the results was carried out to obtain the best possible response surface regression model (Muñoz Sierra et al., 2009) (Table 4, see also Tables S1 and S2.). The F-values of 10.84 and 20.22 for nitrogen and phosphorus removal efficiencies, respectively inferred that the models were significant at less than a $0.05 \%$ level (i.e., $95 \%$ confidence interval). Equations (1) and (2) describe the models containing the significant effects. 
The factors with a value of "Prob $>$ F" higher than 0.050 were excluded from the models since their effect was not significant. It was found that a quadratic response surface model could fit the best the experimental data. Adequate precision of the models were 8.156 and 12.160 for nitrogen and phosphorus removal. A ratio greater than 4 is desirable (Zinatizadeh and Ghaytooli, 2015). Since these values represent the model's differentiation power (Derakhshan et al., 2018), it is expected that the models can be used properly to describe the responses under widespread conditions.

$R_{1}=92.82-0.34 \times A+0.48 \times B-0.61 \times A^{2}-0.69 \times B^{2}$

$R_{2}=95.49+0.061 \times A+2.03 \times B-0.74 \times A^{2}-.034 \times B^{2}$

where $\mathrm{R}_{1}, \mathrm{R}_{2}, \mathrm{~A}$, and $\mathrm{B}$ refer to $\mathrm{TN}$ and $\mathrm{TP}$ removal efficiencies, $\mathrm{HRT}_{\mathrm{AN}}$ and $\mathrm{R}$ (nitrate recycle ratio), respectively.

Fig $\mathrm{S}_{1}$ confirmed the models robustness by exhibiting the predicted vs. actual values of $\mathrm{TN}$ and TP removal. Data points clustered next to the diagonal indicated a satisfactory correlation between the experimental and the predicted values.

Fig 4 depicts the influence of $\mathrm{HRT}_{\mathrm{AN}}$ and $\mathrm{R}$ on $\mathrm{TN}$ and $\mathrm{TP}$ removal (\%) through threedimensional response surfaces. At both high and low values of $\mathrm{HRT}_{\mathrm{AN}}$ and $\mathrm{R}, \mathrm{TN}$ removal efficiency was minimum. At a particular R-value, TN removal efficiency improved when $\mathrm{HRT}_{\mathrm{AN}}$

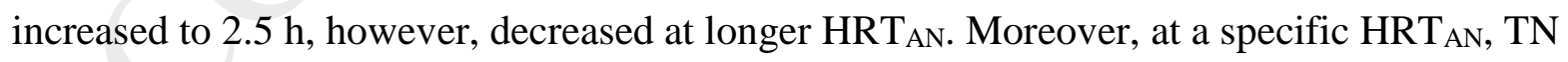
removal efficiency enhanced when $\mathrm{R}$ risen from 0 to 2 and reduced by applying a higher $\mathrm{R}$. $\mathrm{HRT}_{\mathrm{AN}}$ in the range of $2.1-2.9 \mathrm{~h}$ and $\mathrm{R}$ values in the range of $1.6-2.4$ were the conditions for satisfactory TN removal (Fig 4. A)

At low values of $\mathrm{R}$ with both low and high values of $\mathrm{HRT}_{\mathrm{AN}}$, TP removal efficiency was minimum. TP removal showed a positive correlation with increase of $\mathrm{R}$. HRT $\mathrm{AN}$ in the range of 
$1.7-3.4 \mathrm{~h}$ and $\mathrm{R}$ higher than 2 were the satisfactory values for reasonable TP removal efficiency. The maximum TP removal efficiency was approximately $98.3 \%$ when $\mathrm{HRT}_{\mathrm{AN}}$ and $\mathrm{R}$ were $2.5 \mathrm{~h}$ and 4, respectively (Fig 4. B).

\subsubsection{Optimization of $H R T_{A N}$ and $R$}

Optimization was executed through Design-Expert software. The solutions for the optimization of several scenarios to fulfill the maximum $\mathrm{TN}$ and $\mathrm{TP}$ removal efficiencies or minimum $\mathrm{HRT}_{\mathrm{AN}}$ and $\mathrm{R}$ are presented in Fig S2 - S5. For some existing wastewater treatment plants (WWTP), in which there is a shortage of construction site, a minimum $\mathrm{HRT}_{\mathrm{AN}}$ is the crucial parameter to take into consideration (Zeng et al., 2011; Zhao et al., 2016). In some other scenarios, such as low $\mathrm{COD} / \mathrm{N}$ ratios, the key parameter to optimize the performance of the system is the nitrate recycle ratio. Under this circumstance the minimum value of $\mathrm{R}(\leq 3)$ is recommended (2011; Chen et al., 2015). Some municipal wastewater treatment plants must fulfill highly rigorous standards for discharge and in such cases, the maximum TP and TN removal efficiencies are required. According to our study, in the hybrid 5-stage Bardenpho-MBBR system an $\mathrm{HRT}_{\mathrm{AN}}$ of $2 \mathrm{~h}$ and nitrate recycle ratio $\mathrm{R}$ of 2 are the most suitable values in which the TN and TP removal efficiencies were maximized to $92.5 \%$ and $94.7 \%$, respectively. It must be pointed out that TN and $\mathrm{TP}$ removal efficiencies at $\mathrm{R}=0$ in this study were superior to those attained by Wang and Chen (2016), who eliminated the internal recycle in a full-scale anoxic-oxic process, and by Chen et al. (2011); (2015), who determined an R of 3 for an $\mathrm{A}^{2} \mathrm{O}$-biological aerated filter system.

\subsection{Biomass oxygen uptake and nitrification rates}

The specific oxygen uptake rate (SOUR) values revealed the heterotrophic activity (mixed ordinary heterotrophs and PAOs) and exhibited a significant decline from about 58 to $30 \mathrm{mg} \mathrm{\textrm {O } _ { 2 }}$ 
$\mathrm{g}^{-1} \mathrm{VSS}^{-1}$ for suspended solids during runs $1-4$ due to decrease in organic loading rate (Fig 5.A). However, there was a roughly stable behavior for the heterotrophic activity of the suspended solids up to the end of the experiment about $35 \mathrm{mg} \mathrm{O}_{2} \mathrm{~g}^{-1} \mathrm{VSS} \cdot \mathrm{h}^{-1}$. Fluctuations were observed in the attached biofilm, with lower values compared to the suspended biomass $(\leq 10 \mathrm{mg}$ $\mathrm{O}_{2} \mathrm{~g}^{-1} \mathrm{VSS}^{-1}$ ). Nitrification rates exhibited a declining tendency (from about 4 to $0.5 \mathrm{mg} \mathrm{NH}_{4}^{+}-$ $\mathrm{N} \mathrm{g}^{-1} \mathrm{VTS}^{-1}$ ) in suspended biomass due to HRT and $\mathrm{R}$ variations and washout of autotrophic populations (mixed ammonia oxidized bacteria (AOB) and nitrite oxidized bacteria (NOB), Fig 5.B). On the other hand, the autotrophic activity of the attached biofilm decreased only when organic loading rate (OLR) decreased. The autotrophic activity values of attached biofilm were significantly higher compared to the suspended biomass (between 7 to $11 \mathrm{mg} \mathrm{NH}_{4}^{+}-\mathrm{N} \mathrm{g}^{-1} \mathrm{VTS}^{-} \mathrm{h}^{-}$

$\left.{ }^{1}\right)$. On average, the mean nitrifying activity of biofilm was 4 times superior to the nitrifying activity of suspended biomass. Roughly $80 \%$ of nitrification was accomplished by the attached biofilm and $20 \%$ by suspended biomass. The results suggested that suspended biomass exhibited better COD removal. On the other hand, the attached biomass displayed a higher nitrification capability likely due to the biomass retention time of the biofilm on the carriers which is decoupled from the HRT.

\subsection{Biofilm formation}

The attached biofilm thickness at Ae-1 compartment is shown in Fig 6. Within 40 days (start-up period), most of the carriers were fully covered by biofilm (determined by microscopy). Biofilm is a matrix of metabolic activity of cells and extracellular compounds (Flemming et al., 2016; Wang et al., 2018a). Factors such as material and shape of carriers, pH, nutrient levels, iron, oxygen, temperature, microbial activity, extracellular polymeric substances (EPS) concentration, etc. play important roles in formation rate and microbial community composition of biofilm 
(Ansari et al., 2012). The estimated averaged thickness of the biofilm, at Ae-1 compartment, was $1.2 \pm 0.1 \mathrm{~mm}$ and the density was $32 \mathrm{gVSS} / \mathrm{L}$. During day $40-61$, biofilm and floc concentrations increased in all compartments (Fig 7) due to higher total organic loading rate, enhancement of organic loading rate can accelerate the proliferation of biomass in biocarriers (Bassin et al., 2015), while, from day 62 to 125, there was a decrease in both suspended and biofilm biomass concentrations owing to the increase of the total HRT. Similarly, Muda et al. (2011) found that higher total HRT resulted in the reduction of both suspended and biofilm biomass concentrations. Through days 147 - 231, there was a substantial decrease in biofilm concentration in Ao-1 compartment due to $\mathrm{R}$ increase which promoted turbulence in the compartment. Shear force is an important factor in biomass accumulation, and microorganisms detach easily to the bulk liquid with higher shear force (Tang et al., 2017). Correspondingly, there was an increase in suspended biomass concentration originated from the biofilm detachment. Biofilm and suspended biomass concentrations displayed a minor fluctuation during runs 5 to 9 ( $\mathrm{R}$ variation) in other compartments. Fig 8 illustrates the mean values of the suspended and biofilm concentrations inside all compartments. Biofilm concentration at aerobic compartments (Ae-1 and Ae-2) is higher than in other compartments. The secretion and release of extracellular polymeric substance (EPS) by microorganisms can have an effective role in the stability of biofilms against hydraulic stresses (Wang et al., 2018b). EPS had great influences on biofilm formation and adhesion (Gu et al. 2018). Previous studies reported that some microorganisms had a stronger EPS secretion capacity under aerobic environment compared with anoxic and anaerobic environments (Escudié et al., 2011; Zhu et al., 2015)

Recently, in order to provide an insight on the cost effectiveness of nutrient removal, Bashar et al. (2018) considered six full-scale treatment scenarios focused on TP. The processes considered were: (S1) Modified University of Cape Town (MUCT) process, (S2) 5-stage Bardenpho 
Process, (S3) membrane bioreactors (MBRs), (S4) Integrated Fixed-Film Activated Sludge Systems with biofilm Enhanced Biological Phosphorus Removal (IFAS-EBPR), (S5) struvite recovery by chemical precipitation, and (S6) tertiary media filtration. Although 5-stage Bardenpho process appeared to be a very attractive option for enhanced $\mathrm{N}$ removal, the cost for $\mathrm{P}$ removal (\$46.01/lb-P removed) was higher than most of the other scenarios (S1 \$42.25/lb-P, S4 $\$ 42.22 / 1 b-P$, S5 \$44.60/lb-P, S6 \$44.04/lb-P ). MBRs resulted in the highest cost of all scenarios evaluated. IFAS-EBPR was one of the most cost-effective configuration due to low chemical requirement and flexibility to adjust SRT with the contribution of the biofilm without impacting the nitrogen removal capacity of the system. Therefore, it can be inferred that hybrid 5-stage Bardenpho - MBBR might be even more cost effective for both TN and TP removal than the aforementioned technologies.

\section{Conclusions}

The hybrid 5-stage Bardenpho - MBBR system exhibited maximum performance for both organics and nutrients removal under a total HRT of $15.74 \mathrm{~h}$ corresponding to an HRT in the anaerobic compartment of 2 hours and a nitrate recycle ratio of 2 . Satisfactory COD, $\mathrm{NH}_{4}{ }^{+}-\mathrm{N}, \mathrm{TN}$ and TP removal efficiencies were obtained of about $98.20 \%, 96.50 \%, 92.54 \%$ and $94.70 \%$, respectively. Two quadratic response surface models for TN and TP removal displayed a satisfactory and statically significant fitting between the experimental and the predicted values. At a constant HRT, TN removal was promoted when $\mathrm{R}$ increased from 0 to 2 . TP removal presented a positive correlation with higher values of R. Moreover; the attached biofilm enhanced the TN and TP removal by simultaneous nitrification-denitrification (SND) and denitrifying 
phosphorus removal. Nitrification was $80 \%$ accomplished by the attached biofilm and $20 \%$ by the suspended biomass.

\section{Acknowledgements}

This research was financially supported by the Water and Wastewater Co., Bojnord, North

Khorasan Province, Iran. The authors gratefully acknowledge the technicians from the Water Lab of the Department of Water Management at the Delft University of Technology for their support. 


\section{References}

Akratos, C.S., Tsihrintzis, V.A., 2007. Effect of temperature, HRT, vegetation and porous media on removal efficiency of pilot-scale horizontal subsurface flow constructed wetlands. Ecological Engineering 29, 173-191.

Ansari, M.I., Schiwon, K., Malik, A., Grohmann, E., 2012. Biofilm Formation by Environmental Bacteria. in: Malik, A., Grohmann, E. (Eds.). Environmental Protection Strategies for Sustainable Development. Springer Netherlands, Dordrecht, pp. 341-377.

APHA, 2005. Standard methods for the examination of water and wastewater, 21st edn. . American Public Health Association, Washington, DC.

Asadi, Zinatizadeh, Van Loosdrecht, M.C., 2016. High rate simultaneous nutrients removal in a single air lift bioreactor with continuous feed and intermittent discharge regime: Process optimization and effect of feed characteristics. Chemical Engineering Journal 301, 200-209.

Barwal, A., Chaudhary, R., 2014. To study the performance of biocarriers in moving bed biofilm reactor (MBBR) technology and kinetics of biofilm for retrofitting the existing aerobic treatment systems: a review. Reviews in Environmental Science and Bio/Technology 13, 285-299.

Bashar, R., Gungor, K., Karthikeyan, K.G., Barak, P., 2018. Cost effectiveness of phosphorus removal processes in municipal wastewater treatment. Chemosphere 197, 280-290.

Bassin, J.P., Abbas, B., Vilela, C.L.S., Kleerebezem, R., Muyzer, G., Rosado, A.S., van Loosdrecht, M.C.M., Dezotti, M., 2015. Tracking the dynamics of heterotrophs and nitrifiers in moving-bed biofilm reactors operated at different COD/N ratios. Bioresource Technology 192, 131-141.

Bassin, J.P., Dezotti, M., Sant'Anna, G.L., 2011. Nitrification of industrial and domestic saline wastewaters in moving bed biofilm reactor and sequencing batch reactor. Journal of Hazardous Materials $185,242-248$.

Bassin, J.P., Dias, I.N., Cao, S.M.S., Senra, E., Laranjeira, Y., Dezotti, M., 2016. Effect of increasing organic loading rates on the performance of moving-bed biofilm reactors filled with different support media: Assessing the activity of suspended and attached biomass fractions. Process Safety and Environmental Protection 100, 131-141.

Bassin, J.P., Kleerebezem, R., Dezotti, M., van Loosdrecht, M.C.M., 2012. Simultaneous nitrogen and phosphate removal in aerobic granular sludge reactors operated at different temperatures. Water Research $46,3805-3816$.

Bering, S., Mazur, J., Tarnowski, K., Janus, M., Mozia, S., Morawski, A.W., 2018. The application of moving bed bio-reactor (MBBR) in commercial laundry wastewater treatment. Science of The Total Environment 627, 1638-1643. 
Brown, P., Ong, S.K., Lee, Y.-W., 2011. Influence of anoxic and anaerobic hydraulic retention time on biological nitrogen and phosphorus removal in a membrane bioreactor. Desalination 270, 227-232.

Chen, Y., Li, B., Ye, L., Peng, Y., 2015. The combined effects of COD/N ratio and nitrate recycling ratio on nitrogen and phosphorus removal in anaerobic/anoxic/aerobic (A2/O)-biological aerated filter (BAF) systems. Biochemical Engineering Journal 93, 235-242.

Chen, Y., Peng, C., Wang, J., Ye, L., Zhang, L., Peng, Y., 2011. Effect of nitrate recycling ratio on simultaneous biological nutrient removal in a novel anaerobic/anoxic/oxic (A2/O)-biological aerated filter (BAF) system. Bioresource Technology 102, 5722-5727.

De Kreuk, M.K., Kishida, N., Tsuneda, S., van Loosdrecht, M.C.M., 2010. Behavior of polymeric substrates in an aerobic granular sludge system. Water Research 44, 5929-5938.

De Kreuk, M.K., Pronk, M., van Loosdrecht, M.C.M., 2005. Formation of aerobic granules and conversion processes in an aerobic granular sludge reactor at moderate and low temperatures. Water Research 39, 4476-4484.

Derakhshan, Z., Ehrampoush, M.H., Mahvi, A.H., Dehghani, M., Faramarzian, M., Ghaneian, M.T., Mokhtari, M., Ebrahimi, A.A., Fallahzadeh, H., 2018. Evaluation of a moving bed biofilm reactor for simultaneous atrazine, carbon and nutrients removal from aquatic environments: Modeling and optimization. Journal of Industrial and Engineering Chemistry 67, 219-230.

Di Trapani, D., Christensson, M., Torregrossa, M., Viviani, G., Ødegaard, H., 2013. Performance of a hybrid activated sludge/biofilm process for wastewater treatment in a cold climate region: Influence of operating conditions. Biochemical Engineering Journal 77, 214-219.

Di Trapani, D., Di Bella, G., Mannina, G., Torregrossa, M., Viviani, G., 2014. Comparison between moving bed-membrane bioreactor (MB-MBR) and membrane bioreactor (MBR) systems: Influence of wastewater salinity variation. Bioresource Technology 162, 60-69.

Dvořák, L., Lederer, T., Jirků, V., Masák, J., Novák, L., 2014. Removal of aniline, cyanides and diphenylguanidine from industrial wastewater using a full-scale moving bed biofilm reactor. Process Biochemistry 49, 102-109.

Escudié, R., Cresson, R., Delgenès, J.-P., Bernet, N., 2011. Control of start-up and operation of anaerobic biofilm reactors: An overview of 15 years of research. Water Research 45, 1-10.

Flemming, H.-C., Wingender, J., Szewzyk, U., Steinberg, P., Rice, S.A., Kjelleberg, S., 2016. Biofilms: an emergent form of bacterial life. Nature Reviews Microbiology 14, 563.

Fu, Z., Yang, F., Zhou, F., Xue, Y., 2009. Control of COD/N ratio for nutrient removal in a modified membrane bioreactor (MBR) treating high strength wastewater. Bioresource Technology 100, 136-141.

Gallego, D., Muñoz, J.D., Camargo, D., 2009. Evaluation of an alkaline system for CO2 removal: Applied to the upgrading of biogas to natural gas. Ingenieria Quimica 41, 104-111. 
Ge, S., Wang, S., Cao, X., Ma, B., Lu, C., Peng, Y., 2011. Achievement and maintenance of denitrifying phosphorus removal in step feed nutrient removal process. Huagong Xuebao/CIESC Journal 62, 26152622.

Gu, Y.-Q., Li, T.-T., Li, H.-Q., 2018. Biofilm formation monitored by confocal laser scanning microscopy during startup of MBBR operated under different intermittent aeration modes. Process Biochemistry 74, 132-140.

Hoang, V., Delatolla, R., Abujamel, T., Mottawea, W., Gadbois, A., Laflamme, E., Stintzi, A., 2014. Nitrifying moving bed biofilm reactor (MBBR) biofilm and biomass response to long term exposure to $1{ }^{\circ} \mathrm{C}$. Water Research 49, 215-224.

Hu, Z.-r., Wentzel, M.C., Ekama, G.A., 2002. Anoxic growth of phosphate-accumulating organisms (PAOs) in biological nutrient removal activated sludge systems. Water Research 36, 4927-4937.

Huang, X., Dong, W., Wang, H., Jiang, S., 2017. Biological nutrient removal and molecular biological characteristics in an anaerobic-multistage anaerobic/oxic (A-MAO) process to treat municipal wastewater. Bioresource Technology 241, 969-978.

Kermani, M., Bina, B., Movahedian, H., Amin, M.M., Nikaeen, M., 2009. Biological Phosphorus and Nitrogen Removal from Wastewater Using Moving Bed Biofilm Process. Iranian Journal of Biotechnology 7, 19-27.

Kermani, M., Bina, B., Movahedian, H., Amin, M.M., Nikaein, M., 2008. Application of moving bed biofilm process for biological organics and nutrients removal from municipal wastewater. American Journal of Environmental Sciences 4, 675-682.

Lai, T.M., Dang, H.V., Nguyen, D.D., Yim, S., Hur, J., 2011. Wastewater treatment using a modified A2O process based on fiber polypropylene media. Journal of environmental science and health. Part A, Toxic/hazardous substances \& environmental engineering 46, 1068-1074.

Leyva-Díaz, J.C., Muñío, M.M., González-López, J., Poyatos, J.M., 2016. Anaerobic/anoxic/oxic configuration in hybrid moving bed biofilm reactor-membrane bioreactor for nutrient removal from municipal wastewater. Ecological Engineering 91, 449-458.

Li, Y.M., Gu, G.W., Zhao, J.F., Yu, H.Q., Qiu, Y.L., Peng, Y.Z., 2003. Treatment of coke-plant wastewater by biofilm systems for removal of organic compounds and nitrogen. Chemosphere 52, 9971005 .

Lim, E.-T., Jeong, G.-T., Bhang, S.-H., Park, S.-H., Park, D.-H., 2009. Evaluation of pilot-scale modified A2O processes for the removal of nitrogen compounds from sewage. Bioresource Technology 100, 61496154.

Luo, Y., Guo, W., Ngo, H.H., Nghiem, L.D., Hai, F.I., Kang, J., Xia, S., Zhang, Z., Price, W.E., 2014. Removal and fate of micropollutants in a sponge-based moving bed bioreactor. Bioresour Technol 159, 311-319. 
Mannina, G., Capodici, M., Cosenza, A., Di Trapani, D., 2016. Carbon and nutrient biological removal in a University of Cape Town membrane bioreactor: Analysis of a pilot plant operated under two different C/N ratios. Chemical Engineering Journal 296, 289-299.

Mannina, G., Ekama, G.A., Capodici, M., Cosenza, A., Di Trapani, D., Ødegaard, H., 2017. Moving bed membrane bioreactors for carbon and nutrient removal: The effect of $\mathrm{C} / \mathrm{N}$ variation. Biochemical Engineering Journal 125, 31-40.

Mannina, G., Trapani, D.D., Viviani, G., Ødegaard, H., 2011. Modelling and dynamic simulation of hybrid moving bed biofilm reactors: Model concepts and application to a pilot plant. Biochemical Engineering Journal 56, 23-36.

Muda, K., Aris, A., Salim, M.R., Ibrahim, Z., van Loosdrecht, M.C.M., Ahmad, A., Nawahwi, M.Z., 2011. The effect of hydraulic retention time on granular sludge biomass in treating textile wastewater. Water Research 45, 4711-4721.

Mulkerrins, D., Dobson, A.D.W., Colleran, E., 2004. Parameters affecting biological phosphate removal from wastewaters. Environment International 30, 249-259.

Muñoz Sierra, J.D., Camargo Trillos, D.A., Gallego Suárez, D., 2009. Response surface methodology aplication in a $\mathrm{CO} 2$ absorption process from biogas into an alkaline solution. DYNA (Colombia) 76, 135144.

Oberoi, D.P.S., Sogi, D.S., 2017. Utilization of watermelon pulp for lycopene extraction by response surface methodology. Food Chemistry 232, 316-321.

Ødegaard, H., 2006. Innovations in wastewater treatment: -the moving bed biofilm process. Water Science and Technology 53, 17-33.

Ooi, G.T.H., Tang, K., Chhetri, R.K., Kaarsholm, K.M.S., Sundmark, K., Kragelund, C., Litty, K., Christensen, A., Lindholst, S., Sund, C., Christensson, M., Bester, K., Andersen, H.R., 2018. Biological removal of pharmaceuticals from hospital wastewater in a pilot-scale staged moving bed biofilm reactor (MBBR) utilising nitrifying and denitrifying processes. Bioresource Technology 267, 677-687.

Peng, Y., Ge, S., 2011. Enhanced nutrient removal in three types of step feeding process from municipal wastewater. Bioresource Technology 102, 6405-6413.

Reza, M., Cuenca, M.A., 2016. Simultaneous biological removal of nitrogen and phosphorus in a vertical bioreactor. Journal of Environmental Chemical Engineering 4, 130-136.

Tang, B., Zhao, Y., Bin, L., Huang, S., Fu, F., 2017. Variation of the characteristics of biofilm on the semi-suspended bio-carrier produced by a 3D printing technique: Investigation of a whole growing cycle. Bioresource Technology 244, 40-47.

Vishniac, W., Santer, M., 1957. The thiobacilli. Bacteriological reviews 21, 195-213. 
Wang, D., Xu, Q., Yang, W., Chen, H., Li, X., Liao, D., Yang, G., Yang, Q., Zeng, G., 2014. A new configuration of sequencing batch reactor operated as a modified aerobic/extended-idle regime for simultaneously saving reactor volume and enhancing biological phosphorus removal. Biochemical Engineering Journal 87, 15-24.

Wang, J.C., Park, J.K., 2001. Effect of Anaerobic-Aerobic Contact Time on the Change of Internal Storage Energy in Two Different Phosphorus-Accumulating Organisms. Water Environment Research 73, 436-443.

Wang, L., Li, Y., Wang, L., Zhang, H., Zhu, M., Zhang, P., Zhu, X., 2018a. Extracellular polymeric substances affect the responses of multi-species biofilms in the presence of sulfamethizole. Environmental Pollution 235, 283-292.

Wang, L., Li, Y., Wang, L., Zhu, M., Zhu, X., Qian, C., Li, W., 2018b. Responses of biofilm microorganisms from moving bed biofilm reactor to antibiotics exposure: Protective role of extracellular polymeric substances. Bioresource Technology 254, 268-277.

Wang, Q., Chen, Q., 2016. Simultaneous denitrification and denitrifying phosphorus removal in a fullscale anoxic-oxic process without internal recycle treating low strength wastewater. Journal of Environmental Sciences 39, 175-183.

Wang, Y., Peng, Y., Stephenson, T., 2009. Effect of influent nutrient ratios and hydraulic retention time (HRT) on simultaneous phosphorus and nitrogen removal in a two-sludge sequencing batch reactor process. Bioresource Technology 100, 3506-3512.

Wanner, J., 2003. Filamentous Bulking in Activated Sludge, Control of. Encyclopedia of Environmental Microbiology. John Wiley \& Sons, Inc.

$\mathrm{Xu}, \mathrm{S}$., Wu, D., Hu, Z., 2014. Impact of hydraulic retention time on organic and nutrient removal in a membrane coupled sequencing batch reactor. Water Research 55, 12-20.

Yang, W., Syed, W., Zhou, H., 2014. Comparative study on membrane fouling between membranecoupled moving bed biofilm reactor and conventional membrane bioreactor for municipal wastewater treatment. Water science and technology : a journal of the International Association on Water Pollution Research 69, 1021-1027.

Zeng, W., Li, L., Yang, Y.Y., Wang, X.D., Peng, Y.Z., 2011. Denitrifying phosphorus removal and impact of nitrite accumulation on phosphorus removal in a continuous anaerobic-anoxic-aerobic (A2O) process treating domestic wastewater. Enzyme and microbial technology 48, 134-142.

Zhang, M., Peng, Y., Wang, C., Wang, C., Zhao, W., Zeng, W., 2016. Optimization denitrifying phosphorus removal at different hydraulic retention times in a novel anaerobic anoxic oxic-biological contact oxidation process. Biochemical Engineering Journal 106, 26-36. 
Zhao, W., Zhang, Y., Lv, D., Wang, M., Peng, Y., Li, B., 2016. Advanced nitrogen and phosphorus removal in the pre-denitrification anaerobic/anoxic/aerobic nitrification sequence batch reactor (preA2NSBR) treating low carbon/nitrogen (C/N) wastewater. Chemical Engineering Journal 302, 296-304.

Zhu, Y., Zhang, Y., Ren, H.-q., Geng, J.-j., Xu, K., Huang, H., Ding, L.-1., 2015. Physicochemical characteristics and microbial community evolution of biofilms during the start-up period in a moving bed biofilm reactor. Bioresource Technology 180, 345-351.

Zinatizadeh, A.A.L., Ghaytooli, E., 2015. Simultaneous nitrogen and carbon removal from wastewater at different operating conditions in a moving bed biofilm reactor (MBBR): Process modeling and optimization. Journal of the Taiwan Institute of Chemical Engineers 53, 98-111.

Zubrowska-Sudol, M., Walczak, J., 2015. Enhancing combined biological nitrogen and phosphorus removal from wastewater by applying mechanically disintegrated excess sludge. Water Research 76, 1018. 
Fig 1. Diagram of the lab-scale setup of the hybrid 5-stage Bardenpho-MBBR system

Fig 2. Removal performance of the hybrid 5-stage Bardenpho-MBBR system, COD (A), NH4+$\mathrm{N}(\mathrm{B}), \mathrm{TN}(\mathrm{C}), \mathrm{NO} 3--\mathrm{N}(\mathrm{D})$ and $\mathrm{TP}(\mathrm{E})$, each run separated by vertical lines

Fig 3. COD and nutrients concentration within the hybrid 5-stage Bardenpho-MBBR system at HRTAN $=2.5 \mathrm{~h}$ and $\mathrm{R}=2$ (day 62 to 82 ).

Fig 4. Response surfaces for A. TN removal efficiency and B. TP removal efficiency. HRT refers to the anaerobic compartment $\left(\mathrm{HRT}_{\mathrm{AN}}\right)$.

Fig 5. Heterotrophic and autotrophic activities of suspended and attached biomass through experiment, SOUR (A) and nitrifying activity (B)

Fig 6. The attached biofilm development and thickness on the carriers in Ae-1 compartment

Fig 7. The Suspended and biofilm biomass concentration at AN (A), Ao-1 (B), Ae-1 (C) Ao-2 (D) and Ae-2 (E) compartments

\section{Fig.8}




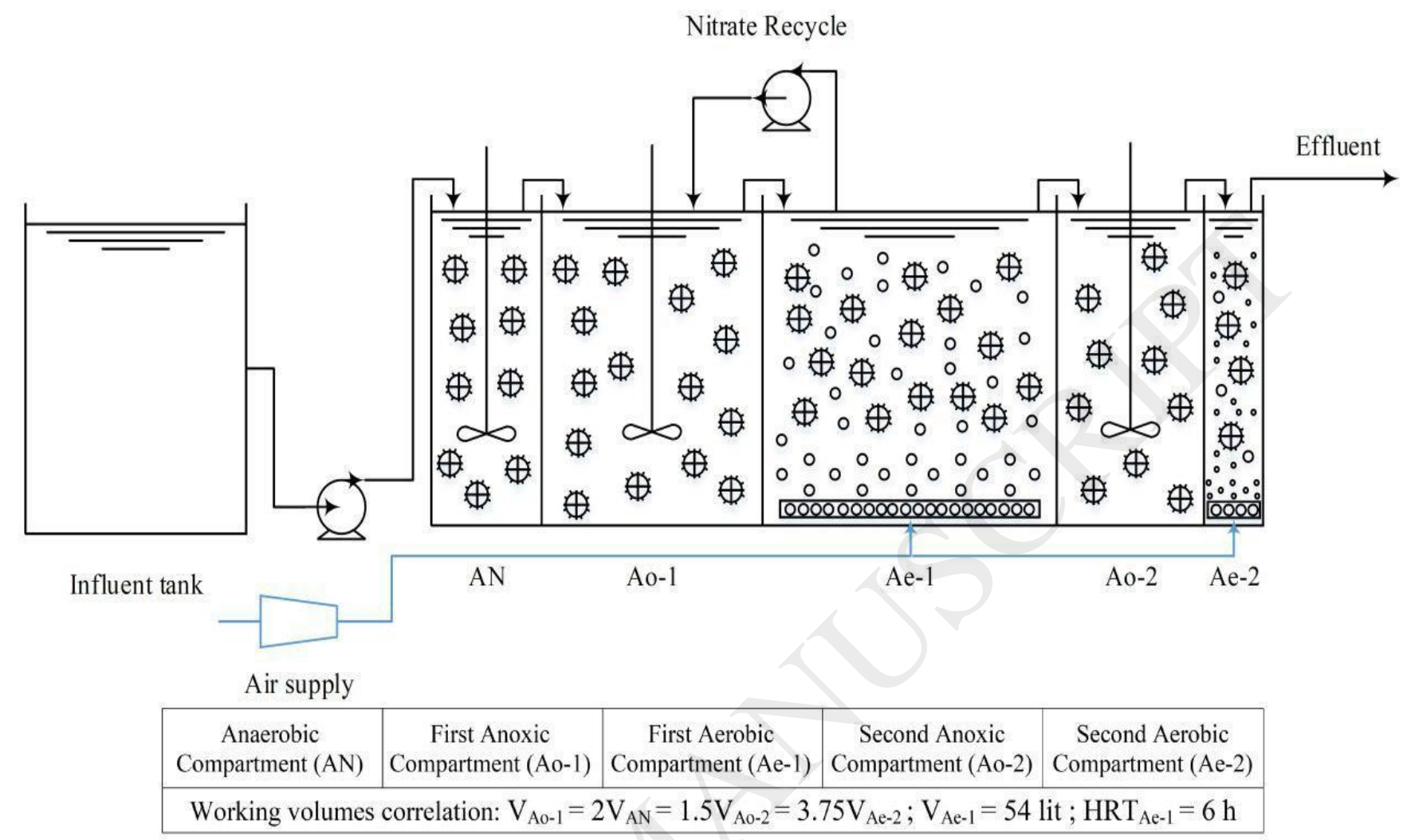

Fig 1. 
(A)

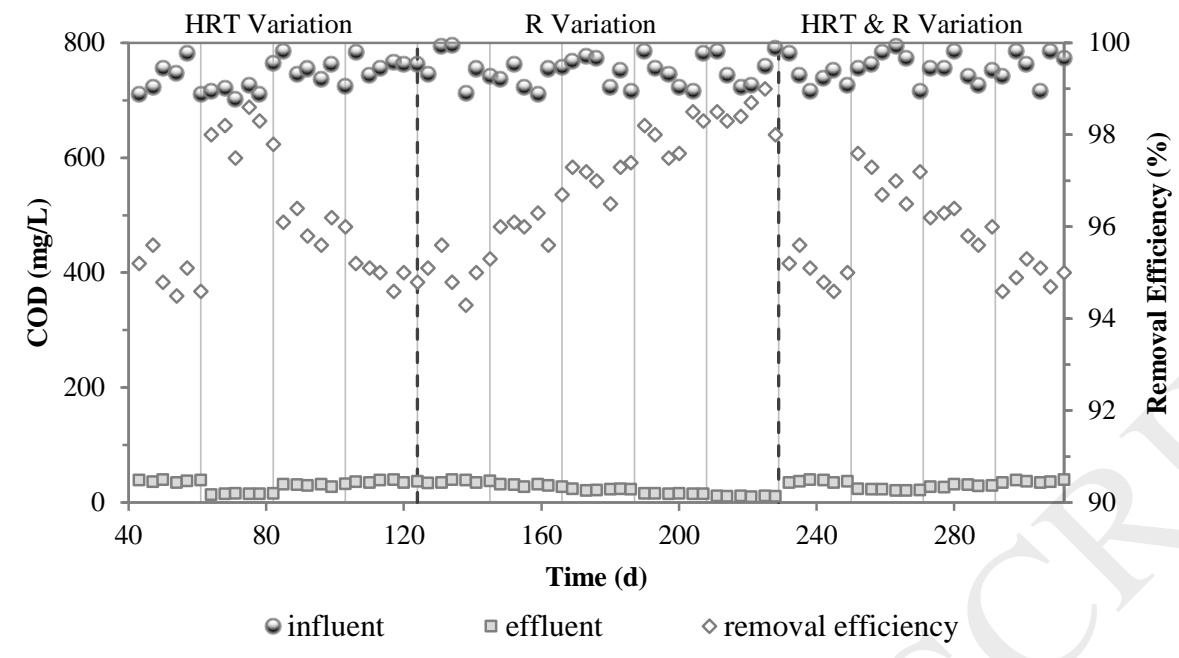

(B)

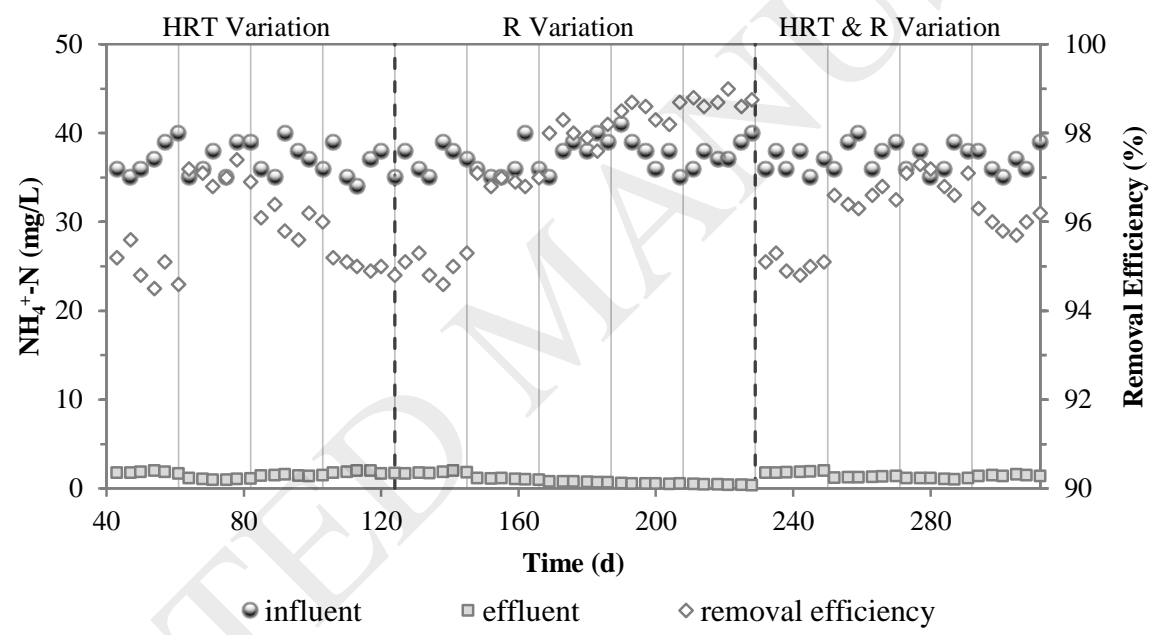

(C)

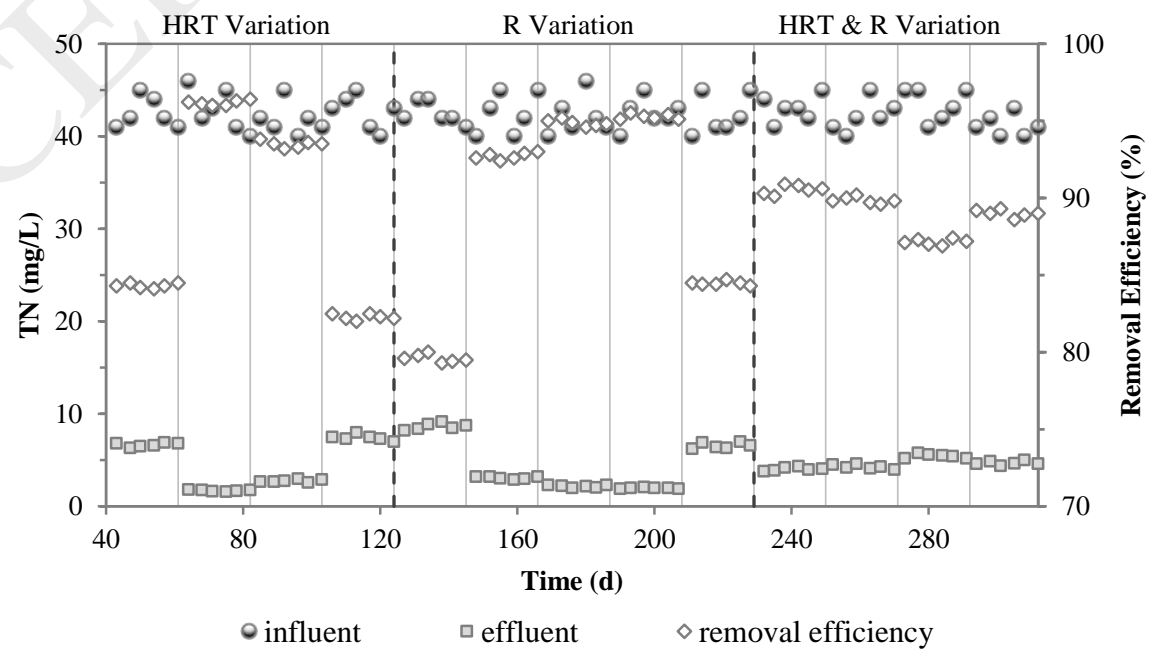


(D)

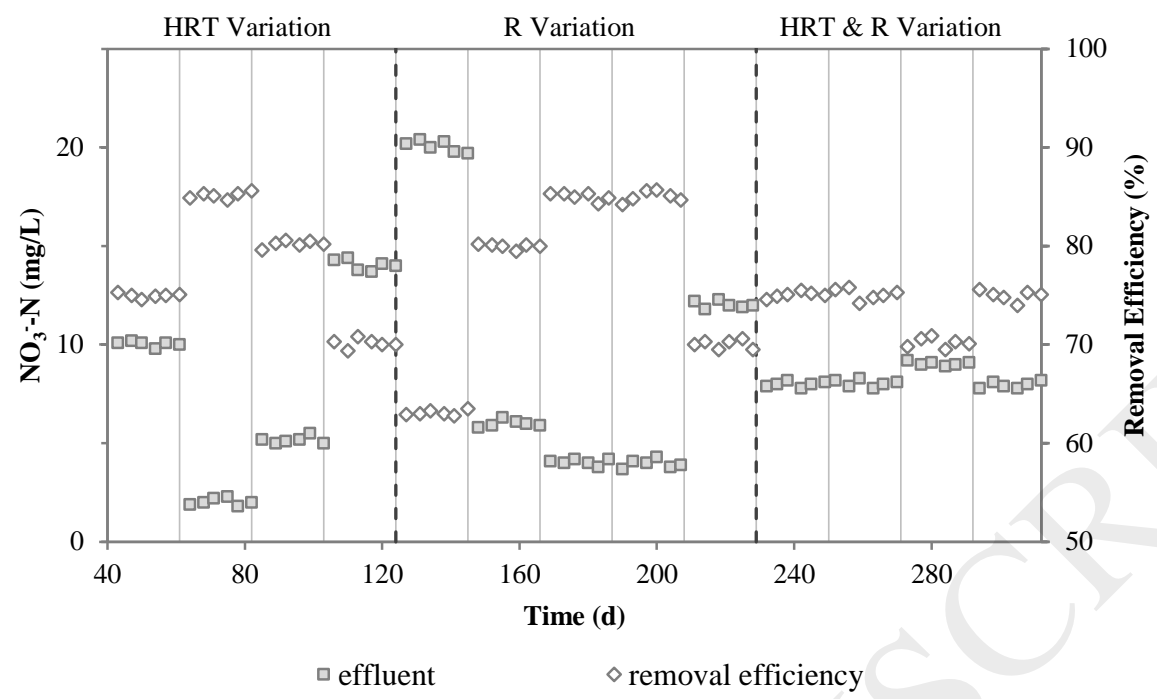

(E)

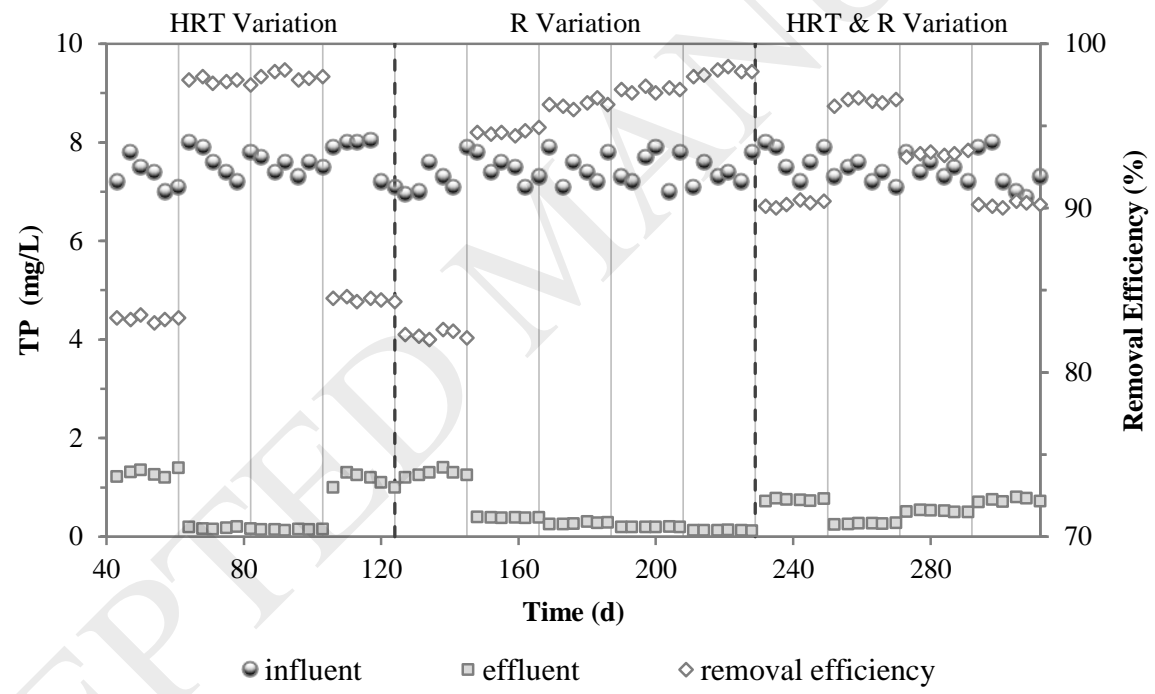

Fig 2. 


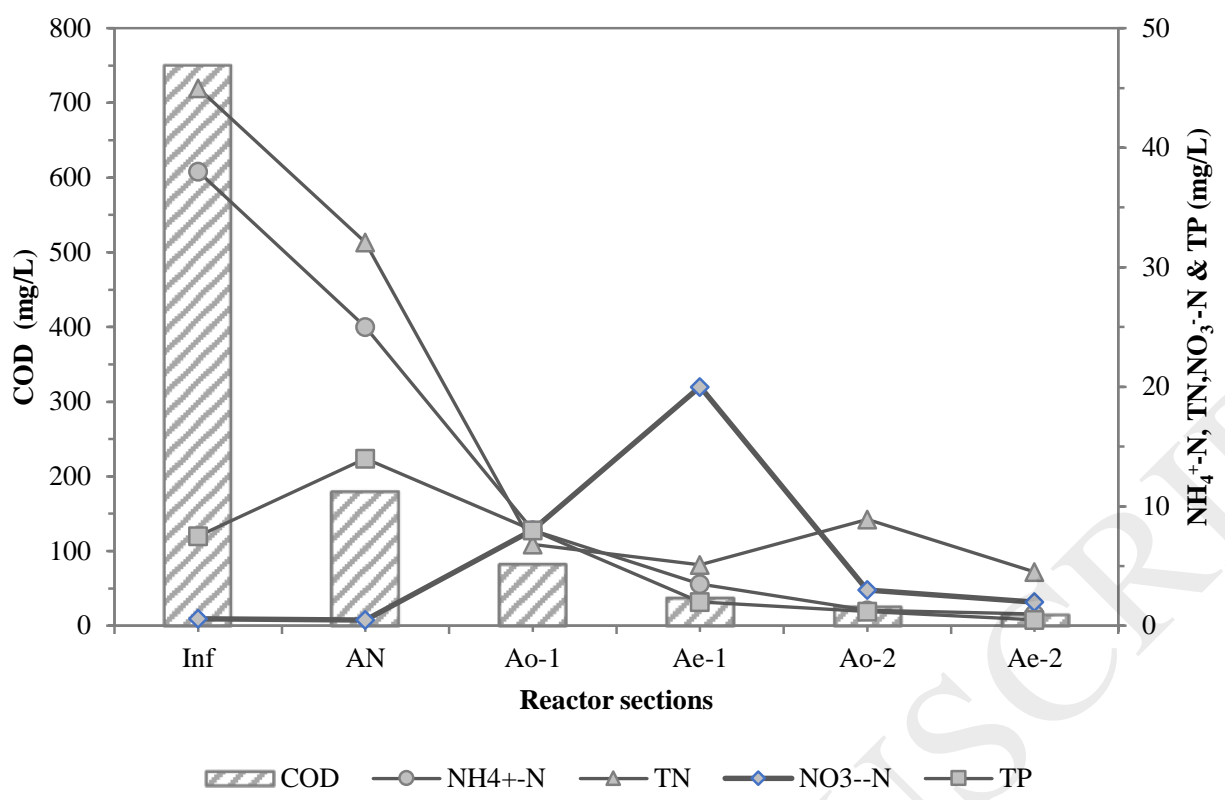

Fig 3. 
A

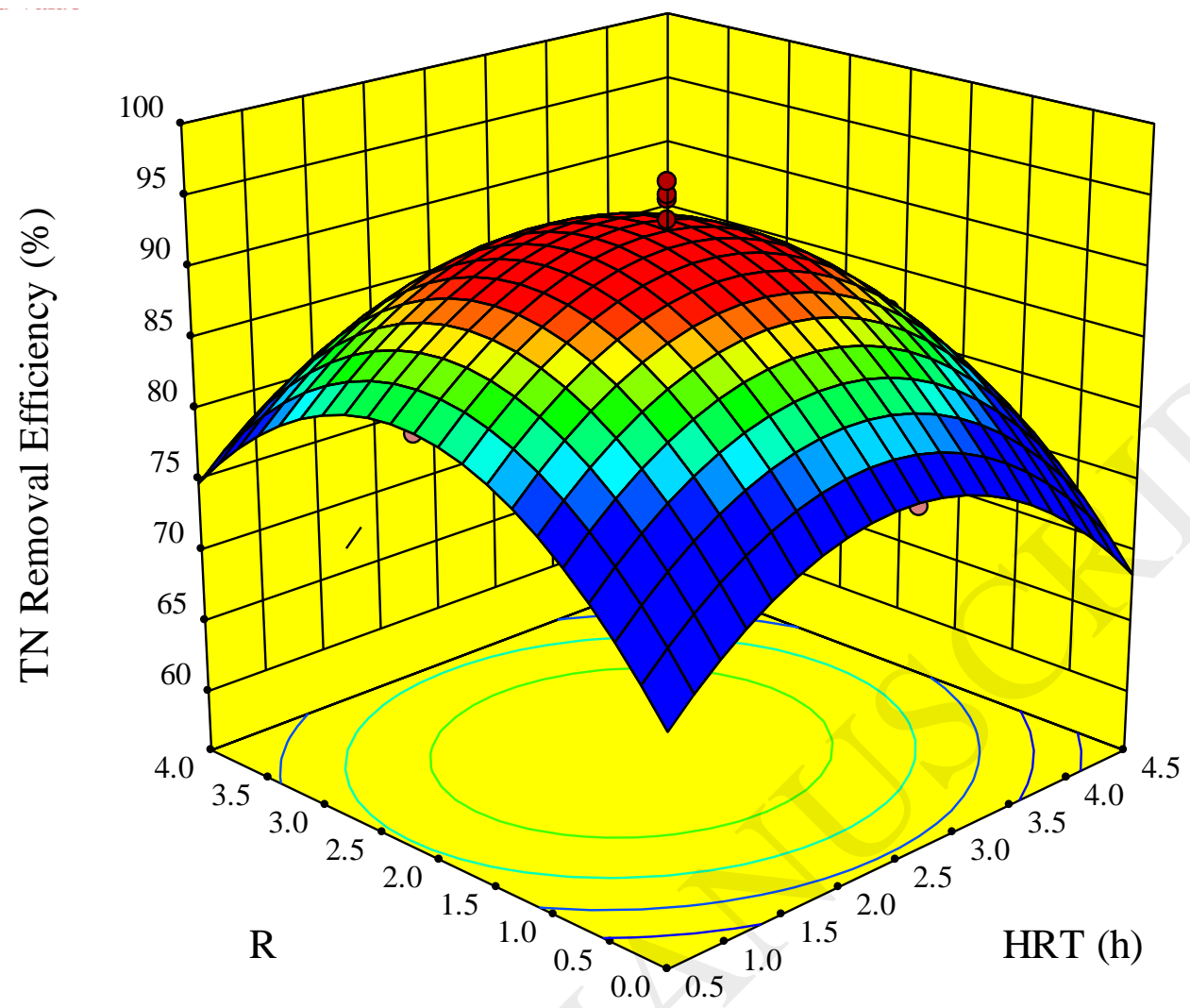

B

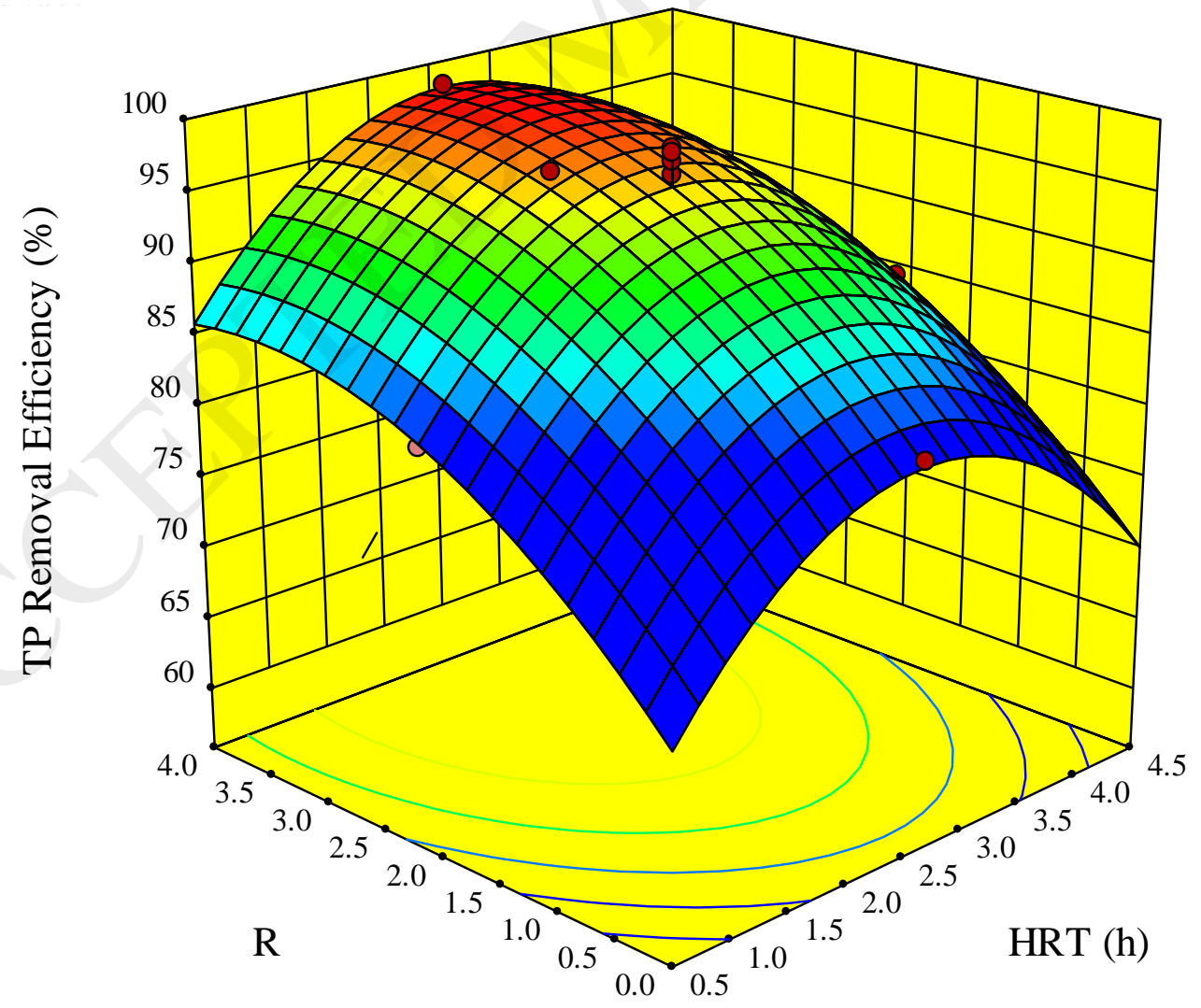


Fig 4.

(A)

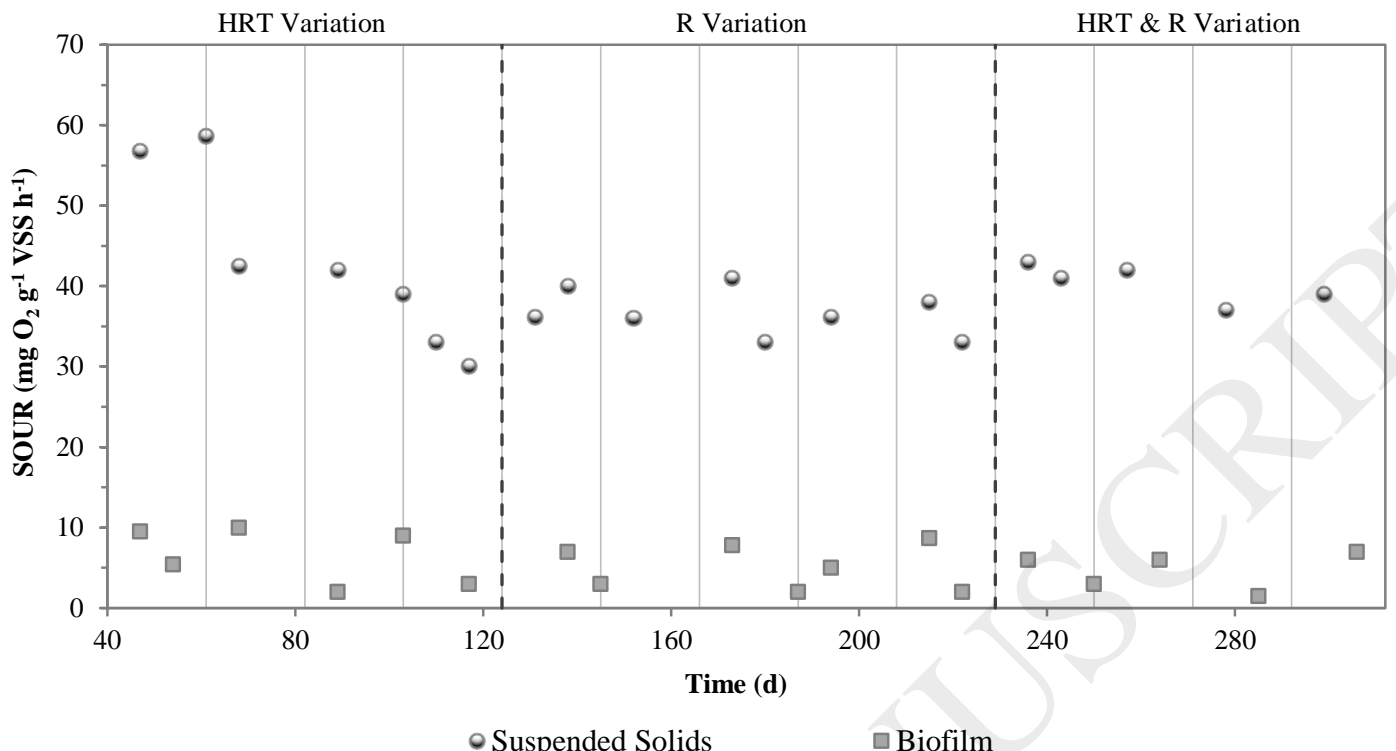

- Suspended Solids

Biofilm

(B)

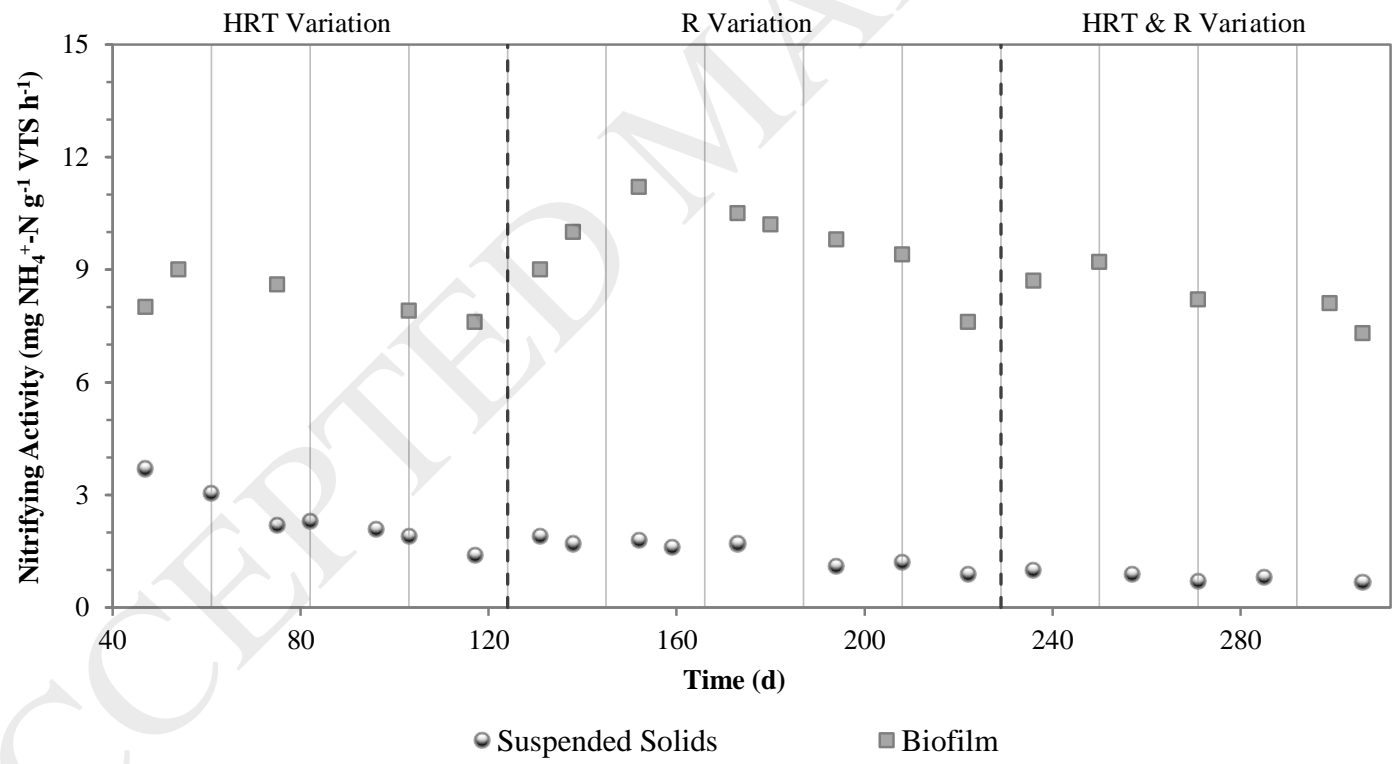

Fig 5. 


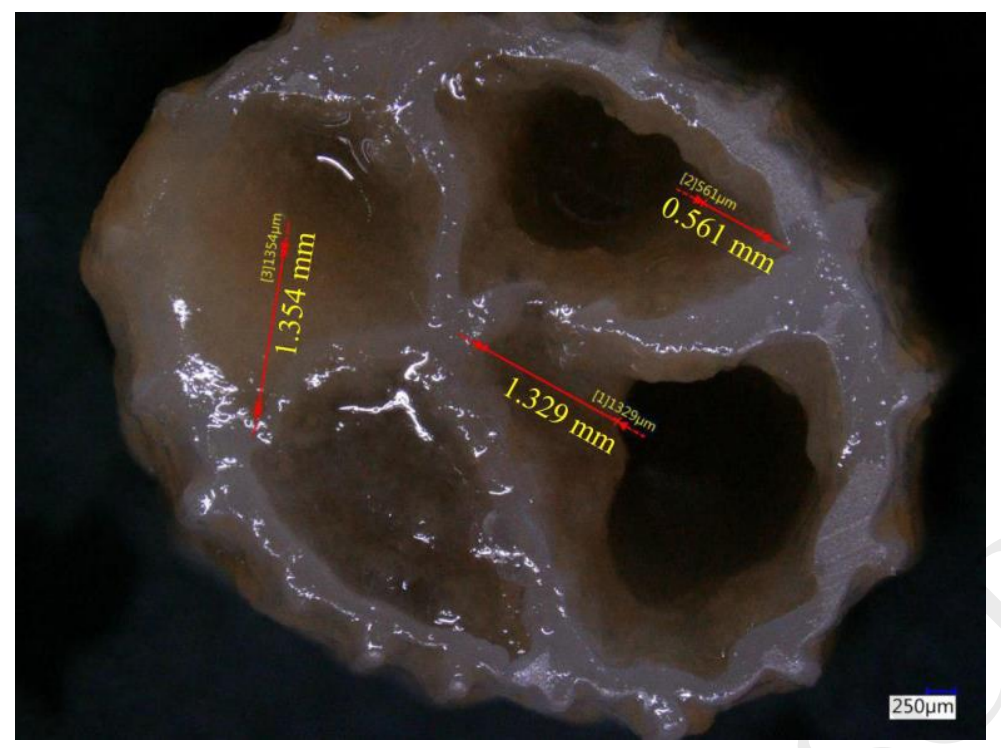

Fig 6. 
(A)

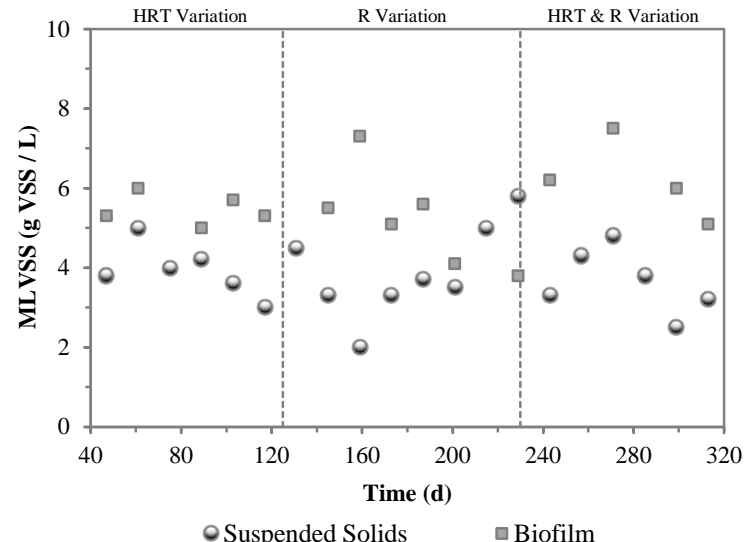

(C)

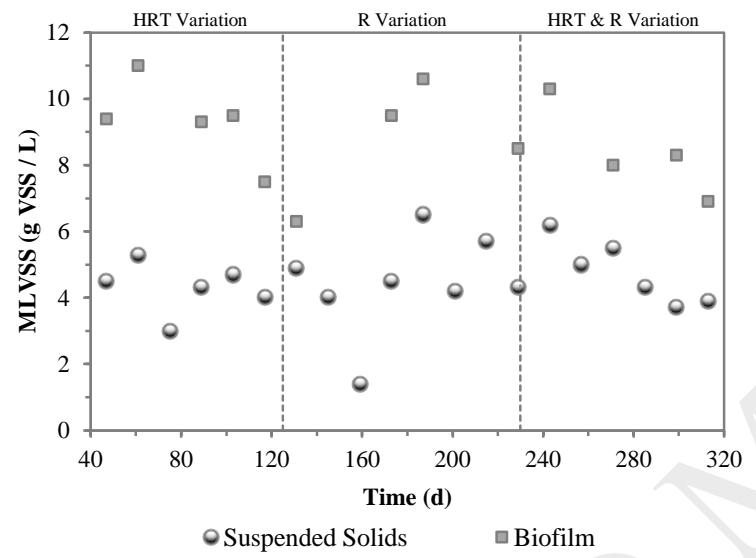

(B)

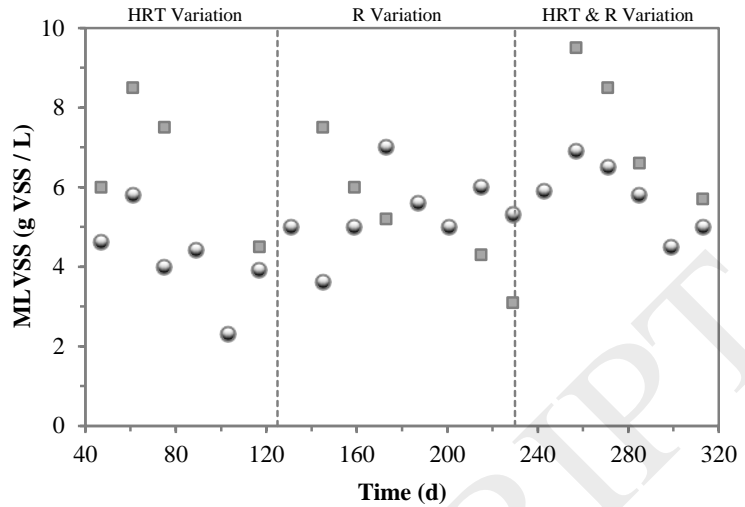

○ Suspended Solids

$\square$ Biofilm

(D)

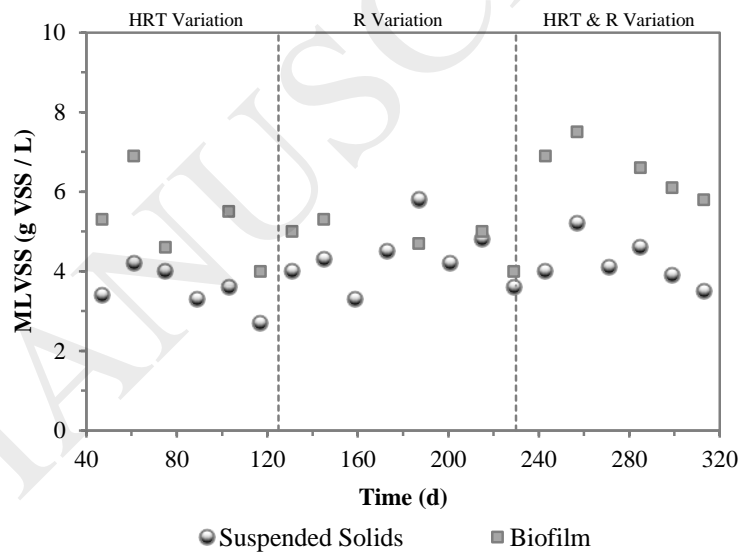

(E)

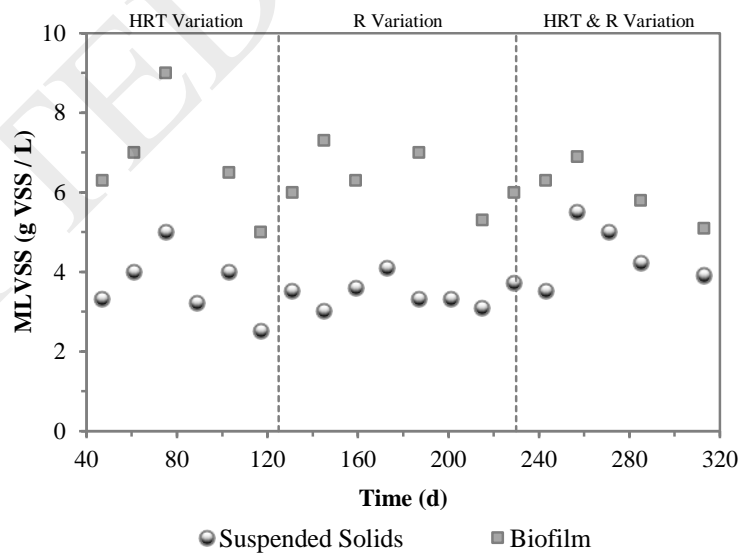

Fig 7. 


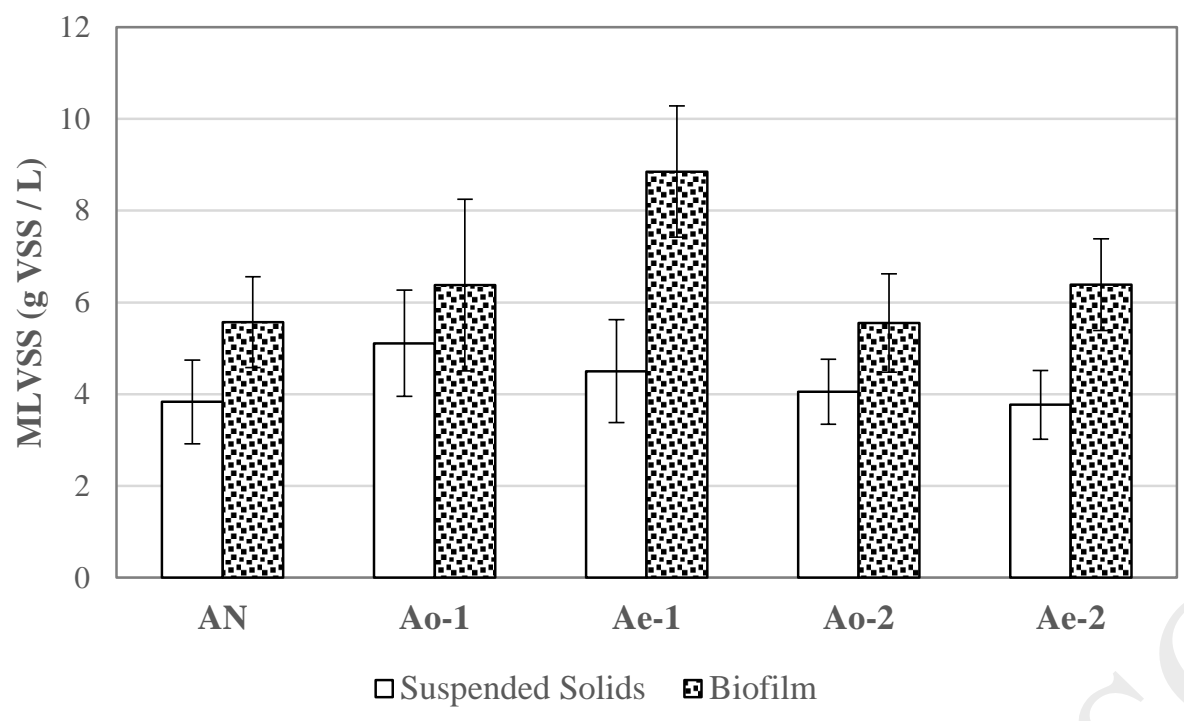

Fig 8 . 
Table 1. Characteristics of Kaldnes $\mathrm{K}_{1}$ carrier

\begin{tabular}{ll}
\hline Characteristics & Kaldnes $K_{1}$
\end{tabular}

\begin{tabular}{lc}
\hline Material & $\begin{array}{c}\text { High-density } \\
\text { polyethylene } \\
\text { Shape }\end{array}$ \\
cylinder \\
Nominal diameter $(\mathbf{m m})$ & 9.1 \\
Nominal length/thickness & 7.2 \\
(mm) & 150 \\
Apparent density $\left(\mathbf{k g} / \mathbf{m}^{\mathbf{3}}\right)$ & 500 \\
Specific surface area $\left(\mathbf{m}^{\mathbf{2}} / \mathbf{m}^{\mathbf{3}}\right)$ & \\
\hline
\end{tabular}


Table 2. Operational conditions of the hybrid 5-stage Bardenpho-MBBR system

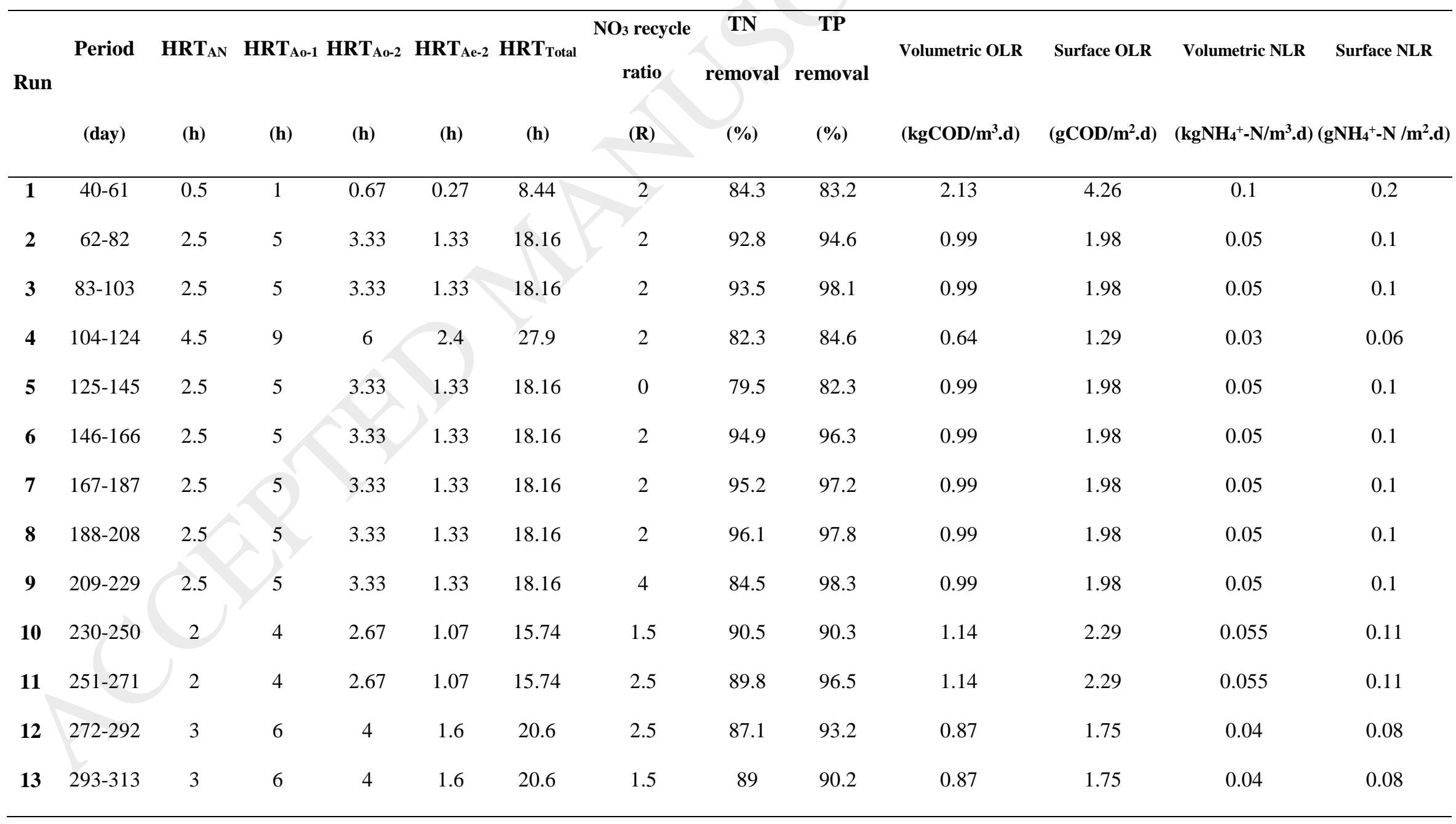


Table 3. Experimental range and levels of the independent variables.

\begin{tabular}{cccccc}
\hline Variable & Low axial & Low factorial & Center & High factorial & High axial \\
& $(-\boldsymbol{\alpha}=\mathbf{- 4})$ & $(\mathbf{- 1})$ & $(\mathbf{0})$ & $(\mathbf{+ 1})$ & $(+\boldsymbol{\alpha}=+\mathbf{4})$ \\
\hline HRT $_{\text {AN }}$ & 0.5 & 2.0 & 2.5 & 3.0 & 4.5 \\
$\mathbf{R}$ & 0.0 & 1.5 & 2.0 & 2.5 & 4 \\
\hline
\end{tabular}


Table 4. Analysis of variance (ANOVA) for the quadratic models.

\begin{tabular}{clcccccccc}
\hline & & $\begin{array}{c}\text { Sum of } \\
\text { Squares }\end{array}$ & df & $\begin{array}{c}\text { Mean } \\
\text { Square }\end{array}$ & F Value & p-Value & Lack of Fit & PRESS & R-Squared \\
\hline $\begin{array}{c}\text { TN } \\
\text { removal }\end{array}$ & Rodel & 288.61 & 4 & 72.15 & 10.84 & 0.0026 & 0.0486 & 444.77 & 0.8442 \\
efficiency & 53.24 & 8 & 6.66 & & & & & \\
\hline $\begin{array}{c}\text { TP } \\
\text { removal } \\
\text { efficiency }\end{array}$ & Model & 376.37 & 4 & 94.09 & 20.22 & 0.0003 & 0.1171 & 444.77 & 0.8442 \\
\hline
\end{tabular}

